Cornell Law Library

Scholarship@Cornell Law: A Digital Repository

Cornell Law Faculty Publications

Faculty Scholarship

$10-1-1987$

\title{
The Transformation of Trusts as a Legal Category, 1800-1914
}

Gregory S. Alexander

Cornell LawSchool,gsa9@cornell.edu

Follow this and additional works at: http://scholarship.law.cornell.edu/facpub

Part of the Estates and Trusts Commons, and the Legal History, Theory and Process Commons

\section{Recommended Citation}

Alexander, Gregory S., "The Transformation of Trusts as a Legal Category, 1800-1914" (1987). Cornell Law Faculty Publications. Paper 469.

http://scholarship.law.cornell.edu/facpub/469

This Article is brought to you for free and open access by the Faculty Scholarship at Scholarship@Cornell Law: A Digital Repository. It has been accepted for inclusion in Cornell Law Faculty Publications by an authorized administrator of Scholarship@Cornell Law: A Digital Repository. For more information, please contact jmp8@cornell.edu. 


\title{
The Transformation of Trusts as a Legal Category, 1800-1914
}

\author{
Gregory S. Alexander
}

Sometimes we are least aware of that which most affects us. So it seems with respect to legal categories. Lawyers do not take legal categories very seriously today. But they should. Legal categories are central to legal reasoning; indeed it is almost impossible to imagine legal reasoning without the use of categories. Categorical thinking affects every area of law. In constitutional law, for example, equal protection analysis turns crucially on categories of affected interests. ${ }^{1}$ Specialists in landlord-tenant law debate whether the implied covenant of habitability is a property doctrine or a contract doctrine. ${ }^{2}$ And if the public/private distinction is dead, as some reports have suggested, ${ }^{3}$ it rules us yet from its grave. ${ }^{4}$ Legal categories are not simply housekeeping devices. They inhibit our imagination of what is acceptable, indeed, of what is possible. They take on a quality of givenness and thereby disempower us. We can retain control over categories, and ultimately over our own legal imagination, only by reminding ourselves that we have created them and are capable of remaking them.

The purpose of this article is to illuminate, through a case-study, the contingent and ideological character of legal categories. It focuses on the development of trusts into and then as a discrete legal category during the period between the beginning of the nineteenth century through the first two

Gregory S. Alexander is Professor of Law, Cornell University. I am indebted to Robert Gordon, Dennis Hutchinson, and Russell Osgood for their suggestions on an earlier draft of this paper. A portion of this paper was presented at the University of Connecticut School of Law. I wish to thank Dean George Schatzki and members of the faculty, particularly Carol Weisbrod, for their comments and support.

1. E.g., in re Griffiths, 413 U.S. 717 (1973) ('strict scrutiny' applied to 'suspect classifications'); Mississippi Univ. for Women v. Hogan, 458 U.S. 718 (1982) ('middle-level' scrutiny applied to gender classifications); Craig v. Boren, 429 U.S. 190 (1976) (same). The whole topic of the steady growth of categorization in constitutional doctrine is discussed in Robert Nagel, 'The Formulaic Constitution', 84 Michigan Law Review 165 (1985).

2. For a critical discussion of this categorical distinction as a theme in recent landlordtenant scholarship, see Edward Chase, 'The Property-Contract Theme in Landlord and Tenant Law', 13 Rutgers-Camden Law Journal 189 (1982).

3. See Duncan Kennedy, 'The Stages of the Decline of the Public/Private Distinction', 130 University of Pennsylvania Law Review 1349 (1982) ('When people hold a symposium about a distinction, it seems almost certain that they feel it is no longer a success.')

4. E.g., Flagg Brothers v. Brooks, 436 U.S. 149 (1978). See also note 19 infra. 
decades of the twentieth century. Nineteenth-century treatises and judicial opinions were filled with discussions about categorical distinctions and the arrangement of law. Categorical ordering was especially conspicuous during the period between 1870 and 1920, the era that, following other recent scholarship, I will call 'Classical', 5 but it was also important in the early part of the century.

Trust law is a particularly appropriate vehicle for studying categorical ordering because it implicates other interlocking categorization problems. Both conceptually and institutionally, trust overlaps with several legal forms, including contract, gift, and conveyance. The legal doctrines governing those forms are based on a conception of duty that is rooted in individualism, while trust law's fiduciary duty suggests communal norms. Trust's relationship with these categories leads to yet another, broader categorical dichotomy, that between law and Equity. ${ }^{6}$ Beneath the surface of that institutional dichotomy lies a political conflict between two conceptions of adjudication, by rule and by discretion. ${ }^{7}$ Nineteenth-century legal theorists, as opposed to judges and treatise writers, both in England and the United States, regarded all of these categorical distinctions as problematic.

There were two stages in the categorical development of trust law. During the first stage, roughly from 1800 to 1875 , courts developed doctrines that sharpened the distinctions between trust and other legal arrangements. The major decisions were English, and American courts followed them with few or no changes. As a result of these doctrines trust law emerged more clearly in legal consciousness as a discrete legal category.

5. In applying the term 'Classical' to this period I am following Duncan Kennedy's lead. See Duncan Kennedy, The Rise and Fall of Classical Legal Thought, 1850-1940 (1975) (unpublished ms.); Duncan Kennedy, 'Toward an Historical Understanding of Legal Consciousness: The Case of Classical Legal Thought in America, 1850-1940', 3 Research in Law and Sociology 3 (1980); Duncan Kennedy, 'Form and Substance in Private Law Adjudication', 89 Harvard Law Review 1685, 1728-31 (1976). However, my use of the term is slightly broader than his. I use it generically, referring to all legal writers who contributed to the classification enterprise during this period as 'Classical'. Kennedy applies it to a distinct mode of legal thought during the same period that attempted rationally to order the entire legal system on the basis of a limited set of core ideas. Some of the writers to whom I refer as Classicists in fact were partial (but only partial) critics of the system of thought that Kennedy brilliantly describes. Holmes, for example, criticized some aspects of Classicism, particularly its pretense to scientism, while adhering to other of its beliefs. See note 23 infra.

Two particularly clear discussions of Classical legal thought are Thomas Grey, 'Langdell's Orthodoxy', 45 University of Pittsburg Law Review 1 (1983) [hereinafter cited as Grey] and Robert Gordon, 'Legal Thought and Legal Practice in the Age of American Enterprise, 1870-1920', in Professions and Professional Ideologies in America, 1730-1940, (Chapel Hill, 1984) 70.

6. The basis for Equity's involvement with trust doctrine, of course, was its historically exclusive jurisdiction over the enforcement of trusts.

7. See Grey, supra note 5 at 48. 
With trusts identified as an autonomous private law category roughly by 1875 , legal scholars during the second stage, the Classical period, focused on the internal classification of trusts. The text that best exemplifies the Classical approach to the internal arrangement of private law subjects was George Costigan's 1914 Harvard Law Review article, ${ }^{8}$ which revised the conventional typology of trusts. ${ }^{9}$

This article will develop the role of legal categories in trust law in four parts. Part I considers general discussions of classification in late nineteenthcentury Anglo-American legal thought. Beginning the specific study of trusts, Part II sketches pre-nineteenth century doctrinal changes that revealed the legal profession's concern with making trust doctrines fit compatibly with analogous common-law doctrines. Part II introduces one of the article's main themes, that throughout the development of what we now think of as the modern law of trusts courts were anxious to prevent equitable doctrines applicable to trusts from undermining analogous common-law doctrines, which even by the late eighteenth century were beginning to reflect an individualistic social outlook. Parts III and IV then tell the article's main story, Part III dealing with the first stage of trust's transformation, its emergence as a clearly distinct legal category, and Part IV discussing the second, Classical, stage.

Legal historians have generally overlooked the development of categorical schemes in American and English law. Classification schemes are worth our attention. They are codes by which participants in the legal system organize and understand their experiences as agents of the system. They are structures of meaning for those who use them. It seems impossible, then, to understand deeply the legal thought of any period without paying attention to its arrangement of legal categories.

\section{Classification in Nineteenth-Century Legal Thought}

This part provides a background for studying the development of trusts as a legal category by describing the role of categorical ordering in late nineteenth-century legal thought. By 'categorical ordering', I mean the process of defining the boundaries of specific categories within which substantive legal concepts operate. ${ }^{10}$ This process occurs at progressively

8. George Costigan, 'The Classification of Trusts as Express, Resulting, and Constructive', 27 Harvard Law Review 437 (1914).

9. See text accompanying notes 151-161 infra.

10. Thomas Grey has elucidated the relationship between legal categories and legal concepts:

[O]ne can distinguish the classificatory categories that demarcate bodies of law (e.g., tort, contract, crime) from the operative concepts used in the principles from which decisive rules are derived (e.g., consideration, proximate cause, malice).

Grey, supra note 5 at 9 , also at 9 n. 28 . 
narrower levels eventually to form a structure that arranges the categories and their subunits hierarchically in relation to each other. ${ }^{11}$ Although categorical ordering appears in English and American legal texts throughout the nineteenth century (and earlier), it was especially prominent in late nineteenth-century writings. Indeed, developing a comprehensive and internally consistent structure of legal categories was a central, if not the central objective of Classical legal thought. That categorical structure still influences our own legal thought. Briefly surveying Classicism's emphasis on categorical ordering at this point will help us later to connect early nineteenth-century doctrinal developments in trust law with the Classical scholarship that analyzed the internal ordering of trust types. ${ }^{12}$

This part also introduces an interpretation ${ }^{13}$ as to why categorical ordering was so important to elite lawyers during the Classical period. This interpretation, which I will apply in the remainder of this paper to various doctrinal developments in the law of trusts, is 'ideological'14 in the sense that it connects seemingly neutral classification schemes with substantive social and political visions.

11. My point here is that arranging categories is not a process distinct from defining the scope of a category. Rather arrangement is inherent in the definition of categories. What also needs to be stressed is that while we tend to think of categorical definition and arrangement as something that is done consciously by legal scholars, it is sometimes also the consequence of doctrinal evolution. This is true in the case of trusts, where the external boundary lines were drawn largely by courts and the internal arrangement made by legal writers.

12. While Classical legal thought as a whole can be understood as a coherent ordering of the legal system, my reference to 'the Classical ordering' should not be misunderstood to suggest legal scholars during the Classical period consciously coordinated their efforts to generate a single arrangement of the law. For the most part they worked in isolation of each other, although they certainly understood their shared methods and values. And their work on categorical ordering operated at differing levels of generality, much of it, like Costigan's, classifying only one area of law at a time. But we can now see how all of these individual efforts hung together to constitute in effect one general ordering of the entire system.

13. I have deliberately chosen the word 'interpretation' rather than 'explanation' because I want to avoid metahistorical questions such as cause and effect relationships between legal ideas and material interests and the extent to which Classical lawyers 'intended' their categorical arrangements to serve the ideological role I describe. My method here is essentially that which Richard Rorty describes in his essay 'Nineteenth-Century Idealism and Twentieth-Century Textualism,' in Richard Rorty, Consequences of Pragmatism (Minneapolis, 1982) 139. Realizing the controversial nature of this approach, I nevertheless will not defend it here, in the interest of getting on with the substantive claim itself.

14. See note 48 and accompanying text, infra. 


\section{A. Categorical Ordering and Classical Legal Thought}

One of the principle achievements of Classical legal thought was its creation of 'a largely new conceptual structure that effectively replaced the older Blackstonian outline of the law in the discourse of the profession'.15 The foundation of this structure was a set of interrelated conceptual distinctions that replaced pre-Classical distinctions. Classical lawyers abandoned some of Blackstone's distinctions altogether, such as person/thing, ${ }^{16}$ rights/wrongs, and absolute rights/relative rights. ${ }^{17}$ Other dichotomies were preserved but in much diluted form. This group includes the law/Equity distinction, which Classical writers like Langdell reduced to being a matter of differences among remedies. ${ }^{18}$ The Classics replaced or supplemented these dichotomies with many of the distinctions that we take for granted

15. Grey, supra note 5 at 47 . The following discussion draws on Grey's illuminating remarks on Classical legal ordering, ibid. at 47-50.

16. For a particularly clear statement of the Classical view of this distinction, see Frederick Pollock, 'Divisions of Law', 8 Harvard Law Review 187, 197 (1894): 'The distinction between law relating to persons and law relating to things may seem to the modern reader . . . not to be a real one ....' In this article Sir Frederick Pollock attempted to connect several of the distinctions familiar to late nineteenth century lawyers with Roman legal classification, specifically, Justinian's Institutes.

17. Duncan Kennedy has discussed these Blackstonian distinctions and explained their oddity to modern eyes in his critique of Blackstone's structure, Kennedy, 'The Structure of Blackstone's Commentaries', 28 Buffalo Law Review 209 (1979).

18. This whole topic of the transformation of the law/Equity distinction very much needs closer study. Some preliminary ideas are sketched out in Grey, supra note 5 at 47-48, and Kennedy, Rise and Fall of Classical Legal Thought', supra note 5 at part III: 52, 55. Some primary sources include, on the American side, C. C. Langdell, Summary of Equity Pleading (Cambridge, Mass., 2d ed., 1883) 27-42 and on the English side, Frederick Pollock, 'The Transformation of Equity', in Essays in Legal History (P. Vinogradoff, ed., London, 1913) 286. It is worth noting here that while Classical writers like Langdell reduced the distinction to a matter of remedies, Realists like Thurman Arnold later resuscitated the law/Equity distinction, transforming it into a dichotomy between two theories of adjudication, by rule and by discretion:

The origin of equity and its persistence today are not due to the hatred of Roman law, or the conservatism of English judges, but rather to the fact that any system which is compelled to reconcile its decisions with its formulated rules must have an escape from those rules. Equity furnished that escape originally. If we are to continue with abstractions, equity must continue to furnish that escape today, even though the two courts are consolidated ... . If the tradition of common law requires abstractions, that same tradition requires that equity be free from them in order to make legal abstractions more elastic.

Thurman Arnold, 'The Restatement of the Law of Trusts', 31 Columbia Law Review 800, 822-23 (1931). 
today. These include the following: public/private, ${ }^{19}$ tort/contract, ${ }^{20}$ objective/subjective, ${ }^{21}$ property/sovereignty, and law/policy. ${ }^{22}$

On both sides of the Atlantic, the Classics deployed these distinctions to organize all of law from the ground up. In the United States the group of lawyer-scholars who published the American Law Review during its formative period led the new movement for more rational arrangements of legal categories. This group included Holmes, John Chipman Gray, Nicholas St. John Green, and James Bradley Thayer. It is no coincidence that all of these individuals were members of law faculties, for academics largely provided the intellectual leadership for the classification effort. As I will discuss later, categorical ordering was a central component of the 'scientific' theory of law that is commonly associated with C. C. Langdell. Indeed, Langdell himself expressly emphasized the importance of legal classification. Other academics who contributed to the classification enterprise included, just to name some of the more prominent figures, John Norton Pomeroy, Melville Bigelow, John Henry Wigmore, William Keener, and George Costigan.

Among the scholarship produced by these individuals, Holmes' famous trilogy of articles published in the American Law Review ${ }^{23}$ was particularly

19. See, e.g., Pollock, supra note 14, at 192 ('A . . . division accepted by almost all systematic writers is that of public and private law.')

For contemporary views on this distinction, see the recent symposium in 130 University of Pennsylvania Law Review 1289 (1982).

20. See, e.g., the famous unsigned article by Holmes, 'The Theory of Tort', 7 American Law Review 652 (1873) and Melville M. Bigelow, Elements of the Law of Torts for the Use of Students (Boston, 1878). Bigelow expressly acknowledged his debt to Holmes's article for his classification of tort duties. See ibid. at $v$.

21. See, e.g., Samuel Williston, 'Mutual Assent in the Formation of Contracts', 14 Illinois Law Review 85, 85-87 (1920).

22. Some of these were the subjects of Realist critiques. Among the more famous of these critiques are Morris Cohen, 'Property and Sovereignty', 13 Cornell Law Review 8 (1927) and Robert Hale, 'Coercion and Distribution in a Supposedly Non-Coercive State' 38 American Political Science Quarterly (1923) 470. One of the greatest ironies of modern legal thought is that for all our post-Realist sophistication, we frequently take these distinctions seriously, acting as though the Realist movement had never occurred.

23. 'Codes, and the Arrangement of the Law', 5 American Law Review 1 (1870); 'Misunderstandings of the Civil Law', 6 American Law Review 37 (1871); 'The Arrangement of the Law-Privity', 7 American Law Review 46 (1872).

My reference to some of these individuals, especially Holmes and Gray, as 'Classical', along with such scholars as Langdell and James Barr Ames, may come as a surprise to some readers. I do not mean to create the impression that there were no significance differences in their respective views. Holmes, for example, was an early critic of certain elements of Langdell's jurisprudence. For my immediate purposes, however, the similarities exceed the differences, and to underscore these similarities, specifically with respect to the importance of legal classification, I find it useful to group them together as 'Classical' writers. See note 5 supra. At the same time, I do think there has been a tendency to exaggerate the extent to which Gray deviated from Classical orthodoxy. 
influential, both at home and in England. ${ }^{24}$ Holmes' main objectives in these essays were to establish the importance of 'philosophical' arrangements of the law generally and to present an outline of his own arrangement, based on duties rather than rights. ${ }^{25}$ Later Classical efforts tended to deal with discrete areas of law, formulating categorical distinctions that defined the nature and boundaries of the field in question. Examples of such work included Wigmore's 'The Tripartite Division of Torts' ${ }^{26}$ Keener's Treatise on the Law of Quasi-Contract, which articulated the Classical distinction between contract and quasi-contract,27 and Costigan's 'The Classification of Trusts as Express, Resulting, and Constructive', which we will examine in detail later.

The major English contributors to the classification project $^{28}$ included

24. See text accompanying note 34 infra. The trans-Atlantic character of the interest in classification is indicated further by the Austin's influence on Holmes and other Classical writers. As evidence of Austin's influence, Gray described Austin's The Province of Jurisprudence Determined as 'considerably in vogue' between 1861 , when Austin's widow republished it, and 1874, when Maine 'dealt it a severe blow in his last two lectures on the "Early History of Institutions" '. John Chipman Gray, 'Some Definitions and Questions in Jurisprudence', 6 Harvard Law Review 21, 22 (1892). Austin's influence on Holmes' thinking is discussed in detail in Mark deWolfe Howe, Justice Oliver Wendell Holmes, vol. II: The Proving Years, 1870-1882 (Cambridge, Mass., 1963) 66-85.

25. See Oliver Wendell Holmes, 'Codes, And the Arrangement of the Law', 5 American Law Review 1, 3 (1870). Reacting to the codification movement, Holmes in this essay argued that 'the most considerable advantage which might be reaped from a code is this: that being executed at the expense of government and not at the risk of the writer, and the whole work being under the control of one head, it will make a philosophically arranged corous juris possible'. Ibid. at 2.

26. John H. Wigmore, 'The Tripartite Division of Torts', 8 Harvard Law Review 200 (1894) (reacting to Holmes's article, 'Privilege, Malice, and Intent', ibid. at 1).

27. William A. Keener, Treatise on the Law of Quasi-Contract (New York, 1893) 16-25. Keener's discussion of the division of contracts into express, implied in fact, and implied in law paved the way for Costigan's later classification of trusts. In particular, his treatment of quasi-contract was the model for Costigan's handling of constructive trust, which is directly analogous to quasi-contract. As I shall discuss in Part IV, both of these concepts were problematic in Classical thought because of their apparent regulatory (i.e., intent-overriding) and communal character. Costigan moved beyond Keener in the sense that he defused the problem not only by isolating the concept from the other types of trusts but also by revising its theoretical foundation (unjust enrichment) in a way that reconciled constructive trust with the other types of trusts. See text accompanying notes 158-61, infra.

28. David Sugarman has discussed the central role of classification in nineteenth-century English legal thought in his excellent study of scholarship produced by the elite English legal academics during the Classical era, David Sugarman, 'Legal Theory, the Common Law Mind and the Making of the Textbook Tradition', in William Twining, ed., Legal Theory and the Common Law (Oxford, 1986) 26. 
Sir Thomas Erskine Holland, ${ }^{29}$ Sir John Salmond, ${ }^{30}$ Sir William Markby, 31 and Sir Frederick Pollock. It does not seem too much of an exaggeration to refer to the classification work of these scholars as a part of a trans-Atlantic project. For although the English and American participants did not explicitly describe their own scholarship as part of a common enterprise, they were certainly aware of the commonality of their interests. They read each others' work and to some extent influenced it. To give just one example of the cross-fertilization that occurred between the leading English and American classifiers, Pollock credited Holmes' classification trilogy as the basis for the arrangement of the multi-volume Encyclopedia of the Laws of England. ${ }^{32}$

Classification also influenced legal education during the Classical period. For example, at Langdell's Harvard Law School, John Chipman Gray explicitly organized his Property course (which strikingly resembles the modern Property course) on the basis of a scheme of classification. He began by distinguishing common law from civil law, then public law from private law. Within private law, he distinguished in personam and in rem rights. This was the crucial distinction. Gray used this distinction to define the scope of the whole category of property: 'The transfer of the rights to things constitutes the law of Property. ${ }^{33}$ His course was literally strewn with the Classical distinctions to which we have referred. ${ }^{34}$

The Classics' need to arrange areas of law, indeed the entire corpus juris, can be traced to several factors. As they saw it, the common law that

29. E.g., Thomas Erskine Holland, Essays upon the Form of the Law (London, 1870); Thomas Erskine Holland, The Elements of Jurisprudence (London, 2d ed., 1882).

30. E.g., John Salmond, Jurisprudence, or the Theory of the Law (London, 1902).

31. E.g., William Markby, Elements of Law, Considered with Reference to Principles of General Jurisprudence (London, 2d ed., 1874).

32. Frederick Pollock, 'General Introduction', Encyclopedia of the Laws of England, 12 vols. (London, 1897) i: 7 n.2.

33. Student notebooks: L. A. Burleigh, 'Notes on Property taught by Prof. J. C. Gray, 1891-92' (Harvard Law School, Manuscripts Collection) 5. Austin Wakeman Scott's student notes from Gray's 1908-1909 Property course include substantially the same definition: 'Property treats of [the] transfer and creation of transferable rights in rem.' Scott notebook at 1 .

34. To cite just one example, L. A. Burleigh's notes include the following statement of Gray's distinction between law and Equity is historical . . . . [T] he main distinction today between law and equity is undoubtedly that which Mr. Langdell insists on so much in his book on Equity Pleading, and that is in the form of remedy.' Burleigh notebook, supra note 33 at 96 .

Gray's emphasis of the in rem/in personam distinction reinforces his standing as a Classic. Duncan Kennedy points out that virtually all of the Classical writers, English and American, agreed that the starting point for the new arrangement of law should be the in rem in personam distinction. Kennedy explains this view as influenced by the will theory. Kennedy, 'The Rise and Fall of Classical Legal Thought', supra note 5 at iv, 31-35. 
they had inherited was bewilderingly jumbled, a 'ragbag of details' ${ }^{35}$ They perceived that the common law itself lacked any workable organization because it had been stamped with the 'old-fashioned English lawyer's idea' that 'a satisfactory body of law was a chaos with a full index'. ${ }^{36}$ Such organization as they could discover in the law itself derived from the old common-law forms of action, and lawyers of the late nineteenth century were anxious to exorcise the common law of the spirits of trover, replevin, detinue, and the like. Mark deWolfe Howe connected the demand for a new arrangement of law with the codification movement of the first half of the nineteenth century. ${ }^{37}$ Codifiers had helped to discredit the old forms of action, and their efforts simultaneously removed an obstacle to more rational classification and intensified the perception that new arrangements were needed. ${ }^{38}$ 'The common law . . . had not felt the need for a philosophical classification of its elements while it had a procedural scaffolding from which the practitioner could pursue his disorderly calling. As the reformers pulled down the scaffolding, the need for carrying forward Bentham's second endeavor - the philosophical-became imperative. By mid-century the time had come for English and American lawyers to offer an arrangement of the law possessing a rational and philosophic strength wholly lacking in the dissolving procedural order of the earlier day. 39

This felt need for a more modern classificatory apparatus echoed another theme that dominated Classical legal consciousness, the vision of legal development as directional and progressive. The progressive vision lead Classical lawyers instrumentally to connect classification with law reform. 'Classification', James DeWitt Andrews stated, ${ }^{0}$ 'has long been recognized

35. Oliver W. Holmes, 'Introduction to the General Survey', in Collected Legal Papers (New York, 1920) 298-301.

36. This phrase is attributed to T. E. Holland by Holmes in his unsigned review of Holland's 'Essays upon the Forms of Law' 5 American Law Review 114 (1870).

37. Mark deWolfe Howe, Justice Oliver Wendell Holmes, vol. 2: The Proving Years, 1870-1882 (Cambridge, Mass., 1963) 62-68.

38. It is important to note that despite their common desire for a rational arrangement of the law, the Classical arrangers identified different functions for their arrangements. Specifically, while Langdell called for 'scientific' classifications, Holmes's plea was for a 'philosophical' classification. The difference was significant, for, as Thomas Grey had pointed out, Holmes rejected Langdell's aspiration for achieving formality in the law through conceptual ordering. That is, in Holmes's view, although conceptual ordering of legal principle was important, legal principles themselves did not decide cases. See Lochner v. New York, 198 U.S. 45, 76 (1905) ('General principles do not decide concrete cases.') Grey, supra note 5 at $8-9$, n.27, 44. Mark deWolfe Howe argued that Holmes, call for a philosophical ordering derived less from his affiliation with the philosophical pragmatists than it did his interest in Austin's command theory of the law. Howe, supra note 32 at ii, 61-95.

39. Ibid. at 65-66.

40. James DeWitt Andrews, 'Classification and Restatement of the Law', 14 Illinois Law Review 465, 622 (1920). 
as a means of reforming the law'. Classification was a matter of 'setting the national law in order' and ridding the legal order of its accumulated anachronisms. In the United States the reformist function of classification was a source of impetus for the Restatement of the Law project, which was first recommended by a special committee of the American Bar Association in 1919.

In addition to these factors, the 'unscientific' and 'unphilosophical' nature of the arrangements made by past generations of treatise writers greatly frustrated Classical scholars. There were two basic types of treatises by the mid-century, and the Classics rejected arrangements contained in both. The first type included the great sweeping works that constituted the backbone of legal education for generations of lawyers prior to 1870 . These included the treatise of Blackstone, Kent, and Story. Remarking on Kent's Commentaries, for example, Holmes, who added many of his own ideas as editor of the famous twelfth edition, gave this blunt evaluation: ' $[\mathrm{H}]$ is [Kent's] arrangement is chaotic - he has no general ideas, except wrong ones . . . '41 The pre-Classical arrangers had done little more than to assemble 'a chaos of cases . . . which lie in a tangled mass across the current of the text, and too often obstruct where they should enlarge'. ${ }^{42}$

The other type of treatise was the self-styled practical treatise aimed at the practicing lawyer. ${ }^{43}$ Classical writers were particularly scornful of the arrangement of law included in these works. Holmes' criticisms again were representative. His main argument was that these practical arrangements in fact were counterproductive. A writer who arrange law according to 'such subjects as railroads or telegraphs ... thinks he is doing a very practical

41. Letter from O. W. Holmes to John Norton Pomeroy, quoted in Howe, supra note 32 at ii: 16.

42. Ibid. Realists later turned this criticism in on Classical reasoning itself. A particularly apt example is Thurman Arnold's attack on the first Restatement of the Law of Trusts. Arnold did not object to classification efforts as such but instead to the method used in the Restatements, which he described as based on definitions and deductions from definitions. He proposed that cases should be arranged 'descriptively'. Echoing the Classics' own line of attack against the pre-Classical arrangements, Arnold stated:

[N]one of the [Restatement's] classifications follow the lines of any particular set of comparable situations, to which a general policy is applicable.

Such classifications do not make the task of the lawyer easier by confining his citations to relevant cases. Instead they compel voluminous briefs and treatises, reconciling the different problems forced under the same abstraction . . . . If the restatement is to clear away the debris and make a new arrangement possible, it must abandon definitions in favor of a simple descriptive process of the purposes for which this logical machinery is used in different kinds of cases.

Arnold, supra note 18 at 814 . On Arnold's role as a Realist see Laura Kalman, Legal Realism at Yale, 1927-1960 (Chapel Hill, 1986) passim.

43. E.g., Thomas G. Shearman \& Amasa Redfield, A Treatise on the Law of Negligence (New York, 1869) (chapters arranged topically include 'Bridges', 'Canals', 'Fences', 'Highways', 'Railroad Fences', and 'Telegraphs'). Holmes, unsigned review of the second edition of this work appears in 5 American Law Review 343 (1871). 
thing'. But by exaggerating legally irrelevant elements such arrangements only exacerbate the confusion. "The methods which are commonly called practical are in truth the most unpractical.' 44 Holmes stated an alternative conception of legal classification that was at once more abstract and more practical, indeed more practical because it was more abstract: 'the end of all classification should be to make the law knowable; and ... the system best accomplishes that purpose which proceeds from the most general conception to the most specific proposition or exception in the order of logical subordination'. 45

While virtually all of the major English and American legal writers between 1870 and 1920 called for more rational arrangements of law, they did not all share the same view about the purpose of classification. Holmes's call for 'philosophical' arrangements was pragmatic in the sense that general categories like contract and tort, unlike narrow categories like telegraphs and railroad fences, focused lawyers' and judges' attention on the legally significant factors. ${ }^{46}$ Classical scholars like Langdell, however, stressed the need for 'scientific' classifications. The legal scientists linked classification with their project of making the legal system complete through formality:

Law, considered as a science, consists of certain principles or doctrines. To have mastery of these as to be able to apply them with constant facility and certainty to the ever-tangled skein of human affairs, is what constitutes a true lawyer . . . If these doctrines could be so classified and arranged that each should be found in its proper place, and no where else, they would cease to be formidable in their number. ${ }^{47}$

44. This statement appears in Holmes, unsigned review of The Code of Iowa in 7 American Law Review 318 (1873).

45. 'The Arrangement of the Law-Privity', 7 American Law Review 46, 47 note (1872).

46. Realists like Karl Llewellyn later turned this argument on its head by pointing out the greater practical value of narrow categories. Appreciating Holmes, criticism of categories that emphasize accidental elements, the Realists developed narrow legal categories along 'functional' lines. See William Twining, Karl Llewellyn and the Realist Movement (Norman, Okla., 1985) 46-50. Thurman Arnold's critique of Austin Wakeman Scott's Restatement of Trusts is an apt example of functional classification. See note 42 supra and 93 infra.

47. C. C. Langdell, Cases on Contracts (Boston, 2d ed., 1879) viii-ix. Langdell and other Classics occasionally carried the connection between classification and legal 'science' to the point of analogizing legal classification and classification in the natural sciences. Pound, who first studied botany at Nebraska under the leading botanist of the time, Charles E. Bessey, before turning to law, later attacked this analogy and the underlying conception of legal classification:

Before the nature of biological classification was well understood, it was often assumed that the unfolding of the idea, which was the reality behind the phenomenon, might be revealed by logical classification. But this is an attempt to explain biological classification philosophically through the idea realizing itself in evolution. It is in some such sense that we are expected to attain 'reality' through classification of law.

Obviously the principles of biological classification are quite inapplicable to the classification of law . . . The assumption that there is some fixed ultimate reality behind legal precepts, which we may discover through analysis or through a 
Yet the philosophical and scientific conceptions of classification were alike in one very important respect. Neither acknowledged that their categorical arrangements reflected substantive value preferences. All of the major participants in the classificatory enterprise described their schemes as purely neutral structures. It is this appearance of neutrality that we will now examine more closely.

\section{B. The Ideological Role of the Classical Arrangement}

Modern lawyers are apt to view the process of defining and arranging legal categorizing pragmatically and therefore as value-neutral. In law, as elsewhere, we can hardly avoid categorizing just to carry on our ordinary activities. We need to organize our information and experiences to be able to use them. Categorical schemes are like the table of contents in a reference book. Just as a table of contents is indispensible in order for the book to serve its purpose, a legal system that lacks some topical arrangement is virtually unthinkable.

Yet, precisely because their function is to organize our accumulated legal norms, categorical schemes do have normative power. By 'making sense' of the vast content of the legal system, they direct our attention and shape our perception of legal norms. In effect, categorical arrangements interpret legal norms, magnifying some concepts and depreciating others. Guiding our attention to some principles as fundamental, they implicitly identify other principles as marginal or aberrational. In this sense categorical schemes are ideological, although not manifestly so. The order that they impose on legal concepts reflects what we can loosely call a world-view, i.e., a coherent bundles of beliefs about the legal system and society in general. 48

Both those who develop and those who use categorical arrangements act within the world-view and are usually not aware of the value judgments that are embedded in their schemes. We can accept as sincere the Classics' claim that their motive was scientific or practical even while we identify their arrangements as ideological. But it is just this unconsciousness about the ideological dimension of categorical schemes that makes them most powerful. For even the scholars who created the scheme understand it not as a contingent artifice, the product of a particular culture, but as a 'glassy

combination of history and analysis, cannot vouch the analogy of taxonomy in biology . . . . Biological classification has found a surer basis for itself, and there is no reason why legal classification may not do the same.

Roscoe Pound, 'Classification of Law', 37 Harvard Law Review 933, 937-38 (1924). Pound's own theory of classification was pragmatic, in contrast with Langdell's. He explicitly 'disclaim[ed] belief that any classification is possible that will enable us to solve problems of substantive law or that will help us much in the solution of such problems'. Instead, 'legal precepts are classified in order to make the materials of the legal system effective for the ends of law'. Ibid. at 939, 944.

48. For a more detailed discussion of this sense of the term 'ideology', see Raymond Geuss, The Idea of a Critical Legal Theory: Habermas and the Frankfurt School (Cambridge, 1981) 9-11. 
essence', ${ }^{49}$ a description of the way things really are. So viewed, the structure is beyond criticizing, except perhaps at its margins, by those who are within the culture whose ideology the structure reflects. Only as the structure recedes in time does its contingent character become apparent. At that point it becomes controversial. Distanced from the culture that created the structure, participants in the legal order gain a perspective from which to understand the structure as cultural and to see and critique its ideology.

As we now view it a century or so later, we are able to understand the categorical scheme that nineteenth-century judges and scholars developed as an expression of a set of value preferences. Sketching the outline of their ideology, the Classics held the following preferences: adjudication by rules rather than discretionary standards, the judicial role restricted to facilitating private intentions rather than public regulation, individual self-determination maximized rather than collective paternalism. ${ }^{50}$ The crucial theory that implemented these preferences was the will theory. Part IV describes this theory in more detail, but for now it is enough to say that the theory basically posited that legal obligations derive either from the will of the parties to a transaction or the will of the sovereign. The hard question in every case was determining whose will controlled, but there was a strong preference in favor of enforcing private will. This theory influenced virtually all of the scholarship on legal classification that appeared between 1870 and 1920.

With respect to the law of trusts, the main ideological dilemma for the Classics was how to accommodate pre-existing collectivist elements in trust law, particularly the constructive trust doctrine, with the individualism that the Classics identified with most types of trusts. Costigan's article illustrates how they used the will theory to reconcile deviationist doctrines with the dominant ideology of private volition. His effort to reformulate the internal arrangement of trust types, however, was possible only after doctrinal developments clarified trust law's status as a discrete legal category within private law. Part II next describes this first stage in the categorical development of trusts.

\section{The Pre-Nineteenth Century Background: Deviations Between Trust and Common-Law Property Rules}

By the beginning of the eighteenth century the Chancellors had shaped trust law substantially in the image of analogous common-law rules.

49. The phrase is Richard Rorty's. He applies it to Cartesian epistemology, while purports to 'ground' knowledge and to 'mirror' nature. See Richard Rorty, Philosophy and the Mirror of Nature (Princeton, 1979) 15-127.

50. The original statement of this set of antinomies and its relevance to legal thought is Duncan Kennedy's comprehensive study of Classical legal thought. Kennedy, The Rise and Fall of Classical Legal Thought, supra note 5. My paper builds on Kennedy's analysis by studying in detail the development of one specific legal category. 
Nevertheless there were areas where Equitable trust doctrines deviated from the common law, and these areas were sufficiently important to make it meaningful to refer, as Patrick Atiyah does, to the 'differing traditions of common law and of equity'. ${ }^{51}$ Equity cases from the latter part of the century on, however, reflect the Equity judges' efforts to reconcile trust with property.

There were two main situations in which the perspectives of Equity and the common law were not entirely compatible. These areas were the law regarding perpetuities and married women's separate estates. Both of these subjects greatly concerned English property lawyers throughout the eighteenth century. A brief discussion of the divergence between law and Equity in these areas illuminates the need that judges like Eldon felt by the end of the century to assimilate trust into property as much as possible.

\section{A. Perpetuities}

The story of perpetuities law is a familiar one to property lawyers and historians of English land law, and I shall not rehearse it here. My purpose is not to add any details to this story but to point out the tension that existed between the legal and equitable responses to the problem of inalienability.

As early as the mid-sixteenth century, following the changes created by the Statute of Uses (1536) and the Statute of Wills (1540), common-law and Equity judges alike faced a dilemma concerning freedom of alienation. Those statutes gave landowners greater latitude to transfer their land as they wished. At the same time, however, landowners could exercise their new power in such a way as to tie up land for long periods of time, thereby frustrating the statutory policy of alienability of land. Although the common-law judges thereafter pursued a relatively consistent course in response to this dilemma well into the seventeenth century, the Chancellor deviated from this course in the most important decision, in law or Equity, concerning property settlements in the seventeenth century, The Duke of Norfolk's Case, ${ }^{52}$ decided in 1670.

During the latter part of the sixteenth century common-law judges developed a number of rules that reflected an aversion to property settlements that made land, or at least risked making land, inalienable. For example, common-law judges held that contingent remainders, which threatened the marketability of land, 53 were destructible and would automatically end if the preceding freehold estate for any reason terminated

51. Patrick S. Atiyah, The Rise and Fall of Freedom of Contract (Oxford, 1979) 134.

52. 2 Swans. 454, 36 Eng. Rep. 690, 3 Chan. Cas. 40, 22 Eng. Rep. 955 (1682).

53. For a discussion of the connection between the recognition of contingent remainders and the creation of settlements that restrained alienation, see Lloyd Bonfield, Marriage Settlements, 1601-1740: The Adoption of the Strict Settlement (Cambridge, 1983) 24-35. 
before the remainder had vested. ${ }^{54}$ This rule enabled grantees to destroy contingent remainders that impeded the marketability of their land. The life tenant conveyed his estate to the owner of the next vested estate, merging those two estates and squeezing out the contingent remainder.

Also reflecting the common-law preference for alienability during this period were the early seventeenth century decisions in which judges refused to allow conveyancers to resurrect the unbarrable entail. Taltarum's Case, 55 which recognized the fictitious common recovery transaction as a device for transforming a fee tail into a fee simple, had dealt a mortal blow to the fee tail as a means for tying up land. Imaginative conveyancers created variations on the basic fee tail, attempting to avoid the common recovery. Recognizing these transactions for what they were, courts struck them down with little effort.

By the first part of the seventeenth century, then, the common law had adopted a fairly clear position in favor of preserving alienability. ${ }^{56}$ To be sure, there were anomalies among common-law decisions. The most notable of these was Pells v. Brown, decided in 1620.57 The Court of Kings Bench held in that case that an executory interest, unlike a contingent remainder, was indestructible. The court elevated what in many situations was a merely verbal distinction between these two types of future interests into a categorical distinction. At a time when they were running out of devices to tie up future ownership of land, conveyancers now had another opportunity to realize their clients' dynastic plans.

Despite its rejection of the destructibility principle with respect to executory interests, we should not interpret Pells as signalling a major shift in the common-law's basic position on the alienability issue in the early seventeenth century. The decision clearly surprised lawyers at the time, as the case's strong dissent suggests. ${ }^{58}$ The fact that the decision was so

54. Chudleigh's Case, 1 Co. 120a, 76 Eng. Rep. 270 (1595); Purefoy v. Rogers, 2 Wms. Saund. 380, 85 Eng. Rep. 270 (1670). See generally George Haskins, 'Extending the Grasp of the Dead Hand: Reflections on the Origin of the Rule Against Perpetuities', 126 University of Pennsylvania Law Review 19, 30-31 (1977).

55. 12 Edw. IV 19, pl 25 (1472).

56. Another datum of the legal 'policy' favoring free alienability that legal historians routinely cite is the rule associated with Shelley's Case, 1 Co. 93b, 76 Eng. Rep. 206 (1581). This rule basically provided that a conveyance to $A$ for life and then to $A$ 's heirs created no contingent remainder in favor of unascertained persons $A$ 's unascertained heirs) but a remainder in $A$.

57. Cro. Jac. 592, 79 Eng. Rep. 504 (1620).

58. Doderidge stated that the decision would lead to a 'mischievous kind of perpetuity'. Ibid., 79 Eng. Rep. at 506. Eighty years after the decision Chief Justice made this observation of the new indestructible executory interests: 'These executory interests had not long been countenanced when the judges repented them; and if it were to be done again, it would never prevail.' Scatterwood v. Edge, 12 Mod. 278, 287, 88 Eng. Rep 1320 (1699). 
surprising itself indicates the basic consistency and strength of the commonlaw efforts to preserve alienability.

In The Duke of Norfolk's Case, ${ }^{59}$ Equity deviated from the apparent course of the common law decisions. Lord Nottingham adopted a conception of a 'perpetuity' which had the effect of recognizing rather extensive powers in settlors to tie up land for a considerable length of time.

The issue in the case was the scope of the term 'perpetuity'. At the time the term had no single fixed meaning. Sometimes courts associated 'perpetuity' with the old unbarrable entail, while other judges had applied it to executory interests. ${ }^{60}$ The thrust of the common-law decisions, however, was that a perpetuity involved any property arrangement that substantially compromised the free alienability of land. That, at least, was the view expressed by the common-law judges whom Nottingham consulted.61 Rejecting their opinions, however, Nottingham concluded that the plan before him did not create a perpetuity because the contingency upon which the gift was made was certain to happen within a short period of time. To borrow Maitland's felicitous metaphor, after Pells v. Brown, the wedge was in, and in The Duke of Norfolk's Case, Nottingham drove it home. Maximum destructibility and alienability were compromised and, contrary to the clear trend of other common-law decisions, the dead hand control of property was extended.

\section{B. Enforcement of the Strict Settlement}

Professor Atiyah has stated that at this time 'Equity, unlike the common law, tended to look more favorably on the importance of ... preserving the institution, even at the expense of the freedom of action of the current generation' ${ }^{62}$ Nottingham's rejection of the opinions of three common-law judges is not the only evidence supporting this observation. The growth of the strict settlement, for which the role of Chancery decisions was critical, ${ }^{63}$

59. 3 Ch. Cas. 1, 22 Eng. Rep. 931 (1682).

60. E.g., Pells v. Brown, Cro. Jac. 592, 79 Eng. Rep. 504, 506 (1620) (dissent).

61. 3 Ch. Cas. at 14, 20, 213, 22 Eng. Rep. at 939, 943, 944.

62. Atiyah, supra note 51 at 134 .

63. See Bonfield, supra note 53 at 58,71 . There is an important recent debate concerning the role of the strict settlement in the formation and preservation of landed family dynasties in eighteenth-century England. The most influential statement of the argument stressing the importance of the strict settlement to dynasts is Sir John Habakkuk's now-classic paper, 'English Landownership, 1680-1740', 10 Economic Historical Review 1 (1940). He has stated his views more recently in 'The Rise and Fall of English Landed Families, 1600-1800', Transactions of the Royal Historical Society, 5th Series, vols. 29 and 30, at 187, 123. Habakkuk's critics include Eileen Spring (see, e.g., 'The Family, Strict Settlements, and Historians', in G. R. Rubin and D. Sugarman, eds., Law, Economy, and Society: Essays in the History of English Law, 1750-1914 (Abindon, 1984)) and Lloyd Bonfield (see Bonfield, supra note 47). See also Lawrence Stone, The Family, Sex and Marriage in England 1500-1800 (London, 
indicates how willing Equity judges were to protect family property trusts whose effect clearly ran contrary to the basic thrust of important commonlaw principles.

The crucial development in the success of the strict settlements was the judicial willingness to recognize the validity of the arrangement's key feature, the trust to preserve contingent remainders. As we have already mentioned, legal (i.e., non-trust) contingent remainders were destructible, and settlors who created them were playing with fire. At the same time, however, the common-law courts recognized another class of future interests, executory interests, which despite their functional similarity to contingent remainders were not subject to the same rule of destructibility. The result was a palpable anomaly. A settlor could create an indestructible contingent future interest if he devised, say, a term to his son for a thousand years, remainder in tail to his oldest grandson living at his son's death. But if the settlor devise to his son a freehold estate, usually a life estate, with the intention of creating the same future interest, his plan might fail because the son could destroy the contingent remainder to the grandson. The seventeenth-century conveyancers developed the trust to preserve contingent remainders to get around this anomaly, and their plans met with success.

The device's main innovation was creating the remainder in favor of trustees during the life tenant's life rather creating it directly in favor of the intended beneficiary. Briefly to illustrate the device, after creating a life estate in A the settlor would insert a limitation to trustees, followed by the desired contingent entail in favor of, say, the settlor's eldest male grandson. If A's life estate happened to terminate prior to A's death, the trust went into operation and in this way saved the contingent remainder from destruction. What is important to notice about this plan is the trust's function is protective. The point of creating the trust is to protect the entire settlement from internal destruction at the hands of the life tenant in possession. In effect, then, the plan presented a trade-off between maintaining the group arrangement, the settlement, on the one hand, or, on the other hand, enforcing the individual freedom of the owner in possession. Successive Chancellors from the late seventeenth and into the seventeenth centuries chose the former option, allowing the trust to perform its protective function despite the common-law destructibility rule. ${ }^{64}$

1977). Because that debate centers on the social and economic consequences of the strict settlement, as distinguished from legal thought and legal ideology, it is largely irrelevant to this paper.

64. The conventional historical wisdom stresses the importance of two decisions from the law courts in resolving the status of the remainder in trustees and hence securing the success of the strict settlement, Duncomb v. Duncomb, 3 Lev. 437 (1697) and Dormer v. Packhurst, 6 Bro. P.C. 351 (1740). See, e.g., A. W. B. Simpson, An Introduction to the History of the Land Law (Oxford, 1961) 214-15. Professor Bonfield has convincingly argued, however, that Chancery had settled the matter before the common-law courts even had an opportunity to address the issue. In these two common-law cases, then, we have an instance of the law following Equity, rather than, as the old maxim had it, the other way around. See Bonfield, supra note 53 at 71-81. 
Nottingham's flexibility in The Duke of Norfolk's Case and the attitude of later Chancellors toward the strict settlement indicate that during the period we have been discussing, there was no firm rule that Equity follows the law, at least not in the context of property settlement trusts. While one must acknowledge that Equity's treatment of trusts did conform to common-law notions more often than not, the point that I want to emphasize is that there were discrepancies on certain critical topics.

\section{Married Women's Separate Estates}

Tension between Equity and the common law regarding alienability was also evident in connection with the subject of married women's separate estates. At common law married women were formally incapable of owning property independently of their spouses. The common law presumed that husband and wife were one person-the husband. By obliterating the wife's legal identity, this doctrine imposed on married women a formal disability to own or control most forms of wealth. During the seventeenth century, the Chancery avoided this restriction by permitting settlors to create trusts for the separate use of married women. ${ }^{65}$ Wealthy fathers who wanted to protect their daughters from being financially dominated by their husbands after marriage could convey or bequeath property in trust to pay the income to their married daughters for their separate uses. ${ }^{66}$

Subsequent Chancery decisions, however, impeded the trust's effectiveness in achieving this protective design. In Hulme $v$. Tennant, ${ }^{67}$ Lord Thurlow held that a husband's personal creditors could enforce a bond which his wife had executed in order to secure her husband's debts against her separate equitable interest. Shortly thereafter, in Pybus v. Smith, ${ }^{68}$ Lord Thurlow enforced a wife's exercise of a power of appointment conveying to her husband's creditor all the equitable interest in a trust that the husband had created for his wife only two weeks before she exercised the power. The reporter of this decision noted that Lord Thurlow had 'a most anxious desire to find any principle of a Court of equity strong enough to protect the property against the improvident act in question', but that under the existing authorities he was constrained to hold that she had 'stripped herself of everything'.

65. For a conventional account of the rise of the married women's separate equitable estate in England, see William Holdsworth, The History of English Law, 16 vols. (London, 1927) v: 309-15. For recent, and excellent, discussions of the law of married women's separate estates in colonial America, see Norma Basch, In the Eyes of the Law: Women, Marriage, and Property in Nineteenth-Century New York (Ithaca, 1982) 70-112 and Marylynn Salmon, 'The Legal Status of Women in Early America: A Reappraisal', Law and History Review 1 (1983) 129, 146-51.

66. John Chipman Gray, Restraints on the Alienation of Property (Boston, $2 \mathrm{~d}$ ed., 1895) $138-40$.

67. 1 Bro. C.C. 16, S.C. 2 Dick. 560 (1778).

68. 3 Bro. C.C. 339,1 Ves. Jr. 189 (1791). 
These cases prompted conveyancers to develop the so-called restraint upon anticipation clause. This device directed that income from the trust be paid to a married woman and not 'be paid by anticipation'. The immediate purpose of the clause was to protect married women as trust beneficiaries from the 'danger of parting with their property under the influence or threats of their husbands' ${ }^{69}$ But the clause also protected the trust itself. By disabling the beneficiary from converting her equitable right to a future stream of income into a fixed capital sum, the restraint effectively made the trust for married women indestructible. Equity judges enforced the restraint clause soon after its appearance in the late eighteenth century. But it was not long before there were indications of misgivings about equitable enforcement of the restraint. In 1817, Lord Eldon declared, with evident regret, that '[i]t is too late now to contend against the validity of a clause in restraint of anticipation' .70

Eldon's reaction against the clause is less surprising than the fact that Equity did enforce it in the late eighteenth century. By this point there was already some evidence of a change in attitude among Equity judges about the relationship between analogous legal and equitable doctrines affecting property settlements. As I will discuss in the next section, Equity jurists became more concerned about establishing greater substantive compatibility. Their concern was especially strong with respect to the issue of restraints on alienation, to which the restraint on anticipation was a first cousin.

The paradox dissolves if we look forward from the eighteenth century to the nineteenth rather than retrospectively examining the enforcement of restraints on anticipation from a nineteenth century perspective. These decisions affirming the restraints in married women's trusts fit squarely in the eighteenth century Equitable tradition of paternalism. ${ }^{71}$ As I have

69. John Chipman Gray, Restraints on the Alienation of Property (Boston, 2d ed., 1895) 139.

70. Jackson v. Hobhouse, 2 Mer. 483, 488 (1817). The early English cases are discussed in Walter G. Hart, 'The Origin of the Restraint upon Anticipation', 40 Law Quarterly Review 221 (1924).

71. Two more examples of Equity's protective tendency in the eighteenth century are its enforcement of so-called 'secret' trusts and its protection of expectant heirs. With respect to the first, Chancery decisions held that a person to whom a decedent had devised property had to comply with the oral understanding under which the decedent had devised the property even though the Statute of Wills seemed to proscribe such oral modifications of wills. See, e.g., Barrow v. Greenough, 3 Ves. 152, 30 Eng. Rep. 943 (1796); Drakeford v. Wilks, 3 Atk. 539, 26 Eng. Rep. I111 (1747). These decisions were protective in two senses. First, they protected the testator's reliance on the devisee's oral representations to carry out the testator's secret dispositive. Second, the purpose of these secret testamentary trusts typically was to protect a second and illegitimate family of the decedent's.

With respect to the second example, throughout the eighteenth century the Court of Chancery very closely scrutinized agreements that expectant heirs made to capitalize their expectancies by selling their birth rights for substantially less than the discounted 
pointed out, the purpose of the clause was to protect married women's economic interests from the predation of husbands. Although the mood was changing in the last decades of the eighteenth century, enough of the protectionist tradition remained to make the clause appealing to Equity judges. Eldon's reaction against the clause was one early manifestation of the shift from the ethos of protectionism to that of self-reliance. This change in the underlying ethical outlook of Equity jurists in the nineteenth century had consequences for the development of trust doctrines as we shall see.

\section{1800-1875: Reconciling Trust Law with Other Legal Categories}

Between the late eighteenth century and the last quarter of the nineteenth century English Equity judges transformed the law of trusts to make it compatible with the law in other areas. Somewhat paradoxically, they did so by assimilating trust and non-trust doctrines at the same time they isolated the law of trusts from other fields. The judges in fact coordinated these two seemingly contradictory strategies of reconciliation, although there is no evidence that they were conscious of doing so. They assimilated or isolated trust depending on the type of issue involved.

The basic distinction was between alienability issues and other issues that did not directly involve alienability. On questions affecting alienability the decisions evidenced a desire to assimilate trust and property law. In cases that did not concern alienability judges increasingly distinguished the trust from other legal forms. This was especially true with respect to the formalities involved in creating a trust. Here the courts developed doctrines that together established the modern 'elements' of a trust. By the end of the period the law of trusts had become an autonomous legal category in the structure of Anglo-American private law.

\section{A. Alienability and The Strategy of Assimilation}

During the first half of the nineteenth century English Equity courts substantially assimilated trust law into the existing body of common-law doctrines regulating restraints on alienation. Two decisions were especially important, Brandon v. Robinson, 72 decided in 1811, and Saunders $v$. Vautier, ${ }^{73}$ decided in 1841.

The conımon-law rules concerning the validity of restraints on alienation were settled well before 1800 , of course. Briefly to sketch these rules as

present value (for 'brown paper and old ginger', Measure for Measure, Act IV, scene iii). Both the social practice and Chancery's unwillingness to countenance these improvident bargains are discussed in P. S. Atiyah, supra note 51 at 172-77 and John P. Dawson, 'Economic Duress-An Essay in Perspective', 45 Michigan Law Review 253, 267-68 (1947).

72. 18 Ves. 429,34 Eng. Rep. 379 (1811).

73. 4 Beav. 115, 49 Eng. Rep. 282 (1841). 
background for the Equity decisions, the validity of any restraint depended on two factors, the type of restraint and the type of estate restrained. ${ }^{74}$ English land law classified restraints into three types, disabling, forfeiture, and promissory. Both disabling and forfeiture restraints were invalid when imposed on fee simple estates. Disabling restraints imposed on life estates were almost never enforced, but forfeiture restraints on life interests were usually upheld, especially if the restraints was created as part of a family property settlement. By prohibiting encumbrances on transferred estates, these common-law rules generally enhanced the alienability of land and also preserved the individual autonomy of the person presently holding the estate.

Brandon v. Robinson substantially incorporated this set of rules into the law of trusts. Eldon held that a disabling restraint could not validly be imposed upon the alienability of an equitable life interest. The trust instrument involved in Brandon stated that the interest of one of the life beneficiaries, Thomas Goom, 'should not be grantable, transferable, or otherwise assignable, by way of anticipation of any unreceived payment . . . ' ${ }^{75}$ Thomas, who was one of the settlor's children, was a true spendthrift, and, as his father had anticipated, he later became bankrupt. One of the creditors sued to enforce his claim against Thomas's equitable interest. Eldon ruled in favor of the creditor, holding that the father's restraint was invalid. Eldon's reasoning is worth examining, for it nicely illustrates his desire to reconcile equitable trust doctrines with established common-law rules.

Eldon first observes that restraints on life interests are valid in law and Equity only in two situations. The first is forfeiture restraints. A forfeiture restraint exists only if the will creating the restraint included words of limitation, such as 'income to be paid to Thomas until he shall become bankrupt'. The conceptualistic reasoning underlying this technical distinction between limitation and condition was that, to use Eldon's words, 'the donor cannot take away the incidents to a life estate'76 and a limitation, but not a condition, 'reduc[es] the interest short of a life estate . . '. ${ }^{77}$ Since Stephen Goom's lawyer failed to use the magical words of limitation, this first exception to the prohibition against restraints did not apply. What is interesting is that Eldon took it for granted that since the will used words of condition the restraint was void. That is, he simply assumed that, without explaining why, the common-law's dichotomy applied to trust interests in

74. The American Legal Realists' attack on the law of property was largely directed against its notorious formalism. As an example, see the critique of the traditional analysis of restraints on alienation in Myres McDougal and David Haber, Property, Wealth, Land: Allocation, Planning, and Development (Charlottesville, 1948) 159-62.

75. 34 Eng. Rep. at 379.

76. Ibid. at 381 .

77. Ibid. 
the same way it did to legal estates, a wooden application of the maxim that Equity follows the law.

The second occasion in which restraints on life interests are valid was the equitable rule concerning restraints on anticipation of married women's trust interests. Here Eldon took pains to rationalize the discrepancy between legal and Equitable perspectives. Eldon's language is worth quoting. Referring to Lord Thurlow, whom he credited with creating the restraint clause, Eldon stated:

He did not attempt to take away any power the Law gave her, as incident to property, which, being a creature of Equity, she could not have at law: but . . Equity, making her the owner of it, and enabling her, as a married woman, to alien, might limit her power over it . . . .78

Eldon's logic in this passage implicitly invoked the gap-filling theory of Equity, according to which Equity's function to merely to supplement the common law where there is no common-law rule. ${ }^{79}$ That theory, which itself neatly mediates the law/Equity dichotomy, applied to the question of the restraint on anticipation clause because, as Eldon pointed out, the common law, not recognizing the legal existence of married women, had no rule concerning restraints on their separate property. As the source of that property interest, Equity could impose, and permit settlors to impose, whatever limits on the married women's separate estate it chose. Equity's recognition of these clauses, then, did not conflict with the common-law prohibition of restraints.

Having resolved the apparent conflict between these legal and Equitable doctrines, Eldon turned to the restraint before him. Obviously the married women's restraints doctrine did not apply since the immediate beneficiary was male. Therefore the validity of Stephen Goom's restraint depended on the common-law condition/limitation distinction.

Thirty years later, Saunders $v$. Vautier extended Eldon's effort in Brandon to assimilate equitable trust and legal property doctrines affecting alienability. The immediate question in Saunders was whether trust beneficiaries could compel trustees to terminate the trust, converting their equitable ownership into legal ownership, before the time designated in the trust instrument. No common-law rules applied, directly or by close analogy to

78. Ibid.

79. This theory conceives the function of Equity to be filling in lacunae, procedural or substantive, in the structure of legal rules. This means that Equity aims at achieving comprehensiveness and completeness in the legal system, rather than moral acceptability. See Grey, supra note 5 at 6-10. On this view, Equitable rules find a civil-law analogue in Francois Geny's hermeneutical analysis of the gap problem in statutory law, expressed his influential book, Method of Interpretation and Sources in Positive Private Law trans. by Jaro Mayda (St. Paul, Minn., 2d ed., 1954). See also Geza Kiss, 'Equity and Law: Judicial Freedom of Discretion', in Science of Legal Method: Selected Essays (Boston, 1917) 146-58 (" [T]he problem of how to apply the law cannot be solved scientifically except by considering the problem of unprovided cases.'). ' 
this narrow issue, nevertheless the decision was important to the enterprise of assimilating trust doctrines within existing common-law property notions. Underlying the technical issue was the same question raised by all of the legal devices we have discussed so far, from entails and strict settlements to the trust restraint on alienation: how far should the settlor's freedom of disposition be permitted to limit the beneficiary's freedom of disposition? Ideological consistency, if not strictly doctrinal symmetry between trust and property rules, was at stake. ${ }^{80}$

The doctrine that is associated with Saunders represented a concomitant victory for the freedom of trust beneficiaries and ideological compatibility between trust and property law. That doctrine, however, is broader than the strict holding in the case, and a clear statement of the so-called Saunders doctrine in fact appears only in subsequent cases. In Saunders itself the plaintiff, immediately after his twenty-first birthday, sought to compel the trustee to transfer the trust property to him outright, i.e., as legal owner. The plaintiff was sole beneficiary of the trust and therefore had the equivalent of an equitable fee simple absolute interest. ${ }^{81}$ The trust instrument, however, expressly provided that the trust was to continue until the beneficiary was twenty-five, so the petition in effect asked the court to disregard a restraint on anticipation.

Ruling in favor of the beneficiary, the court merely applied a wellestablished rule in the law of wills. According to this rule, the sole legatee of a vested interest could demand immediate payment of the capital sum of the legacy even though the will expressly stated that the executor should postpone payment and accumulate the income for a stated period of time. ${ }^{82}$ Since the trust instrument in Saunders was a will and the trust had only one

80. Michael Chesterman, in an illuminating discussion of Saunders $v$. Vautier, points out that by this time premature termination of trusts raised 'relatively novel concerns of equity'. Chesterman, 'Family Settlements on Trust: Landowners and the Rising Bourgeoisie', in G. R. Rubin and D. Sugarman, eds., Law, Economy and Society, 1750-1914: Essays in the History of English Law (Abindon, 1984) 124, 152. This was because the case coincided with a transformation in the form that trust property took. The traditional practice of settling specific, usually family, land in a trust was being replaced at the time by a new trust practice, trusts of investments. These new trusts did not presuppose, as did the old trust of land, that the trustees would hold any specific asset. Rather they were flexible vehicles for settling the rising forms of non-landed wealth, including intangible personally such as government stock. Since these forms of wealth were unknown at common law, the old legal rules that developed around trusts of land were not as obviously relevant. Conceding Chesterman's observation, my argument is that compatibility between trust and property still remained an issue in the trust termination matter because of the ideological significance of freeing the trust beneficiary from a restriction imposed by the 'dead hand' of the settlor.

81. The court concluded that postponement of the time when the beneficiary could possess the trust estate did not impose any requirement that he survive to that time. This conclusion followed the constructional principle announced in Clobberie's Case, 2 Vent. 342, 86 Eng. Rep. 476 (Ch. 1677).

82. Lord Pawlet's Case, 2 Ventris 366 (1685). 
beneficiary, the holding required only a simple extension of this rule to testamentary trusts.

By the following year, however, Chancery had expanded this narrow ruling into the much broader doctrine that lawyers today associate with Saunders. ${ }^{83}$ Under the so-called Saunders doctrine a court will order premature termination of any trust, even one having multiple beneficiaries, so long as all beneficiaries are sui juris and consent to termination. The first case to expand the Saunders holding into this broader form was Curtis $v$. Luken. ${ }^{84}$

There is little doubt that the Brandon rule prohibiting trust restraints on alienation facilitated Chancery's expansion of the Saunders decision into a general doctrine permitting premature termination. The Master of the Rolls acknowledged this connection in Curtis:

[The beneficiary] has the legal power of disposing of it, he may sell, charge, or assign it, for he has an absolute indefeasible interest in a thing defined and certain; the Court, therefore, has thought fit . . . to say, that since the legatee has such the legal right and power over the property, and can deal with it as he please, it will not subject him to the disadvantage of raising money by selling or charging his interest, when the thing is his own, at this very moment. ${ }^{85}$

The court recognized that since equitable trust interests are freely assignable it would be fruitless to enforce the settlor's attempt to postpone the beneficiaries' receipt of the trust property. Beneficiaries could accomplish indirectly what the restraint on anticipation prevented them from accomplishing directly merely by selling their equitable interests for a fixed sum.

The Brandon and Saunders doctrines in fact were mutually reinforcing. While the Brandon rule facilitated Chancery's expansion of the Saunders holding, the now-broadened Saunders doctrine neatly dovetailed with the Brandon rule by recognizing the beneficiaries' power to deal freely with their trust interests. The combined effect of the two doctrines was to shift the power to control the continued existence and membership of any trust from settlor to beneficiary. By changing its position in the trade-off between settlor and beneficiary, Equity retreated from its protectionist tradition and established ideological compatibility between trust law and individualistic common-law property rules.

It is important to appreciate how the Saunders doctrine signalled this move away from the protectionist thrust of earlier equitable doctrines and toward the individualistic tendency of common-law rules of property. I noted earlier that at least from the late seventeenth century through the eighteenth century, when enforcing family property arrangements Equity

83. Curtis v. Luken, 5 Beav. I47, 49 Eng. Rep. 533 (Ch. 1842).

84. Ibid.

85. Ibid. at 156, 49 Eng. Rep. at 536. 
tended to protect institutions at the expense of individual freedom. ${ }^{86}$ Equity's protection of strict settlements and trusts for married women were the outstanding examples of this tendency. ${ }^{87}$ The Saunders doctrine, by refusing to preserve trusts against attacks from within by beneficiaries, meant that Equity had reversed its preference. It was now, in the midnineteenth century, willing to sacrifice trusts for the sake of the beneficiaries' individual autonomy. On the crucial issue of alienability, trust and property had been substantially assimilated. ${ }^{88}$

\section{B. The Strategy of Isolation: Formalizing the Trust Model}

During the same period that they assimilated trust and property alienability doctrines, English Equity judges developed other trust doctrines that categorically separated trust from other areas of law. In this section I will discuss two important examples of these boundary-drawing doctrines, Richards v. Delbridge, ${ }^{89}$ which effectively abandoned Ex parte Pye, ${ }^{90}$ and Morice v. The Bishop of Durham. ${ }^{91}$ I will also briefly discuss the trust res requirement. By drawing categorical lines between trust and analogous legal, i.e., common-law, arrangement, these doctrines aided the process of developing a classificatory structure of private law that made all of its categories appear to fit harmoniously together.

\section{Formalities: From Ex parte Pye to Richards v. Delbridge}

Modern legal theory defines the trust form in terms of discrete 'elements'.

86. See text accompanying notes $62-64$ supra.

87. Equity continued to enforce strict settlements and trusts for married women into the nineteenth century, of course. My point is that the protectionist ethic that had led Equity judges to enforce these devices in the late seventeenth century and throughout the eighteenth century substantially eroded during the mid-nineteenth century and that the emergence of the Saunders doctrine clearly signalled this change.

88. This state of compatibility existed in American as well as English law through most of the nineteenth century. Indicating this compatibility, John Chipman Gray in 1883 stated that the symmetrical treatment of restraints on equitable and legal interests was 'settled law'. John C. Gray, Restraints on the Alienation of Property (Boston, 1883) iii. With few exceptions, American courts applied the English Brandon and Saunders doctrines. E.g., Gray v. Obear, 54 Ga. 231 (I875) (applying Saunders); Thompson v. Ballard, 70 Md. 10, 16 Atl. 378 (1889) (same); Philadelphia v. Girard, 45 Pa. 9, 27 (1863) (same); Smith v. Moore, 37 Ala. 327, (1861) (applying Brandon); Tillinghast v. Bradford, 5 R.I. 205 (1858) (same); Mebane v. Mebane, 39 N.C. (4 Ired. Eq.) 131 (1845) (same).

Begin with Justice Miller's famous dictum in Nichols v. Eaton, 91 U.S. 716 (1875), however, American courts sharply deviated from the English dead-hand trust doctrines. During the three decades American state courts adopted the so-called spendthrift trust doctrine and the Claflin doctrine. I have discussed these developments at length in Gregory S. Alexander, 'The Dead Hand and the Law of Trusts in the Nineteenth Century', 37 Stanford Law Review 1189 (1985).

89. L.R. 18 Eq. 11 (Ch. 1874).

90. 18 Ves. 140, 34 Eng. Rep. 271 (Ch. 1811).

91. 10 Ves. 522, 32 Eng. Rep. 947 (Ch. 1805). 
Textbooks typically state that in order for any trust to exist there must be a specific trust res, a trustee, and a beneficiary. ${ }^{92}$ Together these elements constitute the model of a trust.

Although the origin of each of these requirements certainly predates the nineteenth century, it was not until the middle of that century that English and American legal thought abstracted them into constituents of a formal model. In describing a trust model that was 'abstract' and 'formal', I mean that legal analysis did not, and for the most part still does not, distinguish between functionally different trusts. ${ }^{93}$ Courts applied the same model to business and bankruptcy trusts as they used to analyze whether a gratuitous family trust existed. Nor did they distinguish between long-term 'dynastic' trusts and short-term 'caretaker' trusts. 94

This formal trust model was crucial to the emergence of trust law as an autonomous legal category. Equity courts in the nineteenth century increasingly emphasized the model's elements in sharpening the lines between trust and similar legal categories. Judicial reasoning made the decisions appear to flow inexorably from the legal category that the parties themselves selected, even if mistakenly. And whether trust was the appropriate category depended on whether all of the elements of a trust were in place.

The doctrine that Equity will not cure an imperfect gift by treating the transaction as a trust illustrates this formalization process. Despite the principle that equitable doctrines never deviated from the common-law rules governing property transfers, ${ }^{95}$ during the eighteenth century and into the early nineteenth century the Chancellor in fact sometimes overlooked technical legal requirements. This is essentially what Eldon did in Ex parte

92. The continued force of this trust model is indicated by the way in which the study of trusts is structured in modern law-school casebooks and by the organization of the Restatement (Second) of the Law of Trusts. The familiar format identifies three constitutive 'elements'-trust property, trustee, and beneficiary-and structures the study of legal disputes involving the creation of trusts according to these elements. For example, the trust property requirement is used to distinguish trust from other forms of consensual legal obligations, including agency, debt, and bailment, that involve lower standards of duty.

93. Thurman Arnold attacked the nineteenth-century ordering of trusts, which he associated with the Restatement of Trusts (see Arnold, supra note 18 at $802 \mathrm{n.4}$ ), on precisely this ground. Conceptual abstractions, which led to the categorical distinctions between trust and debt, trust and bailment, and the like, ignored the functional differences and dissimilarities among the usages of the term 'trust'. He wanted to reverse trust's development, in effect advocating the death of trust by 'mov[ing] away from "Trusts" as a body of definable principles'. Ibid. at $802 \mathrm{n} .5$. A glance at any of the most popular law-school casebooks on trusts and estates indicates how little of the Realist critique was integrated into mainstream legal thought except to the extent that Trusts is now seldom offered as a free-standing course. Austin Wakeman Scott's treatise on trusts is devoid of virtually any Realist influence.

94. See Lawrence Friedman, 'The Dynastic Trust', 73 Yale Law Journal 547 (1964).

95. This principle grew out of the conception of Equity as merely a supplement of the common law. 
Pye. In Pye, a man named Mowbray attempted to provide for a female friend by purchasing an annuity for her benefit. It does not seem insignificant that the intended beneficiary, Marie Garos, was the mother of three children fathered by Mowbray, who was married to another woman. To carry out the arrangement Mowbray instructed his agent in Paris to purchase an annuity in Ms. Garos's name. Learning that she was married 'and also deranged', 96 the agent instead purchased the annuity in Mowbray's name. Mowbray then sent his agent a written power of attorney authorizing the agent to transfer the annuity to Marie. Mowbray died about a year later, but his agent, not knowing of Mowbray's death, exercised the power of attorney thereafter. (The report indicates that by the time of the agent's action Ms. Garos's husband had died and she was 'of sound mind'. ${ }^{97}$ ) Under English law the power of attorney terminated immediately upon Mowbray's death, and the agent could not effectively exercise it. Eldon concluded, however, that the written power of attorney constituted Mowbray's declaration that he held the annuity in trust for Ms. Garos.

Pye vividly exemplifies Eldon's complex and paradoxical thought, belying his conventional image as a thorough-going conservative. ${ }^{98}$ In Pye, Eldon held that the owner of personal property can declare himself a trustee of the property for the benefit of another even though he receives no consideration for the declaration of trust. No prior Equity decision had recognized the validity of a gratuitous declaration of trust, but Eldon enforced Mowbray's arrangement on that ground without even discussing the point. ${ }^{99}$ The other striking aspect of the case is the fact that, even assuming the general validity of gratuitous declarations of trust, Mowbray's evident intent was to give the annuity to Ms. Garos outright, rather than to hold it in trust for her. Eldon's conclusion on both of these issues created tension between trust doctrine and established common-law rules.

With respect to the validity of gratuitous declarations of trust, the problem that Eldon's decision created relates to the common-law's antipathy toward gratuitous promises. For, from one point of view a person's declaration that he henceforth holds some asset in trust for the benefit of another looks very much like a promise to do an act in the future. Suppose, for example, a person declares, 'I have decided to give these

96. 34 Eng. Rep. at 272.

97. Ibid.

98. In an illuminating discussion of the paradoxes in Eldon's legal thought, Patrick Atiyah indicates why it is so misleading to apply labels like 'conservative' to figures during this period. P. S. Atiyah, supra note 51 at 362-69.

99. The case has a reputation as a curiosity, in part because of Eldon's failure to raise this legal question. See, e.g., Austin Wakeman Scott, The Law of Trusts, 6 vols. (Boston, 3d ed., 1967) i: 236-37; Harlan F. Stone, 'The Nature of the Rights of the Cestui Que Trust' , 17 Columbia Law Review 467, 474 (1917); Forrest v. Forrest, L.R. 34 Eq. 428 , 432 (1865). 
bonds to Susan when she graduates from college next month.' It is not difficult to imagine that someone hearing this utterance might understand it to mean the same as the following statement: 'I am holding these bonds for Susan until she graduates next month when I will turn them over to her.' As a matter of ordinary speech habits, the difference between the two declarations is subtle at best, but the legal difference is very great. The first is a promise to make a gift, unenforceable if not supported by consideration, while the second is a declaration of trust, enforceable in Equity even if it is entirely gratuitous. It is just because the two forms of utterances can sound so much alike that Pye's recognition of the trust declaration threatened to undermine the common-law rule on gratuitous promises.

We can view the trust declaration in either of two ways, from the standpoint of contract law or the law of gifts. Which of the two, if either, Eldon adopted is uncertain since he failed even to acknowledge the novelty of his decision to enforce a gratuitous declaration of trust. ${ }^{100}$ However, Eldon's decision is anomalous from both points of view.

Looked at from the perspective of contract law, the immediate problem with the arrangement in Pye concerns the consideration requirement. To be sure, Equity's conception of consideration was not identical to the commonlaw's requirement, but Equity did not enforce gratuitous promises to give to a donee. ${ }^{101}$ These decisions illustrated one meaning of the maxim that Equity will not aid a volunteer. ${ }^{102}$ The real force of that maxim depended on who were 'volunteers'. Assuming for the moment that Mowbray intended to make himself a trustee, was an intended trust beneficiary who was unrelated by blood to the declarant more than a 'mere volunteer'?103 If not, then

100. It is, of course, possible that his decision did not follow from legal reasoning at all but instead simply on sympathy with Mowbray's predicament, a situation with which he is not likely to have been altogether unfamiliar. Plucknett's observation that Eldon's 'scrupulous character would not permit him to decide a case until he had exhausted all its possibilities and examined it from every angle' (Theodore F. T. Plucknett, $A$ Concise History of the Common Law (Boston, 5d ed., 1956) 707) notwithstanding, Eldon was not beyond reaching legal conclusions on the basis of pure bias. See P. S. Atiyah, supra note 51 at 362 .

101. E.g., Antrobus v. Smith, 12 Ves. 39, 46; Edwards v. Jones, 1 My. \& Cr. 647, 671.

102. Lord Cottenham's statement in Jeffreys v. Jeffreys, Cr. \& P. 138, 141, 41 Eng. Rep. 443 (1841) that 'the court will not execute a voluntary contract', of course, postdated Pye, but the notion did not originate in that case.

103. The protean character of the term 'volunteer' is suggested by Lord Henley's discussion of the consideration requirement in Equity:

I say I know no instance where a court of equity has compelled a man to execute what was a mere act of volition. But I think the present was not a mere voluntary agreement, and the court will . . . attend to slight considerations for confirming family settlement and modifications of property. They pay a regard to reasonable motives and honorable intentions . . . . They consider the ease and comfort and security of families as a sufficient consideration. 
Eldon's decision created a curious discrepancy in both the treatment of gratuitous undertakings: the statement 'I promise' was unenforceable, both at common law and in Equity, while the statement 'I declare' was enforceable in Equity but unenforceable at law. ${ }^{104}$

Some writers have attempted to rationalize Pye by suggesting that Eldon viewed the case from the perspective of gift rather than promise. ${ }^{105}$ Even if we view the arrangement in Pye as a gift of an equitable interest, Eldon's decision is no less anomalous. From this perspective the problem is the common-law requirement of delivery. At common law parol gifts of legal interests in personal property (including annuities) are valid only if the donor delivers the asset, or some permissible substitute, to the donee. Pye in effect authorized individuals to donate equitable, rather than legal, interests in the same asset by a merely verbal act. Stating 'I give' without delivering possession has no legal effect; stating 'I declare a trust' effectively transfers beneficial ownership, i.e., everything except title. Whether one views the transaction from the perspective of contract law (promise) or property law (gift), then, the gratuitous trust declaration dispensed with formalities required for closely analogous transactions.

The second anomaly involved in Pye relates directly to the lack of formality of equitable gift-making. The disparity between the formality required for trust declarations and that prescribed by the law of gifts presented an obvious opportunity for Equity judges to enforce gratuitous undertakings where the donor had not attempted to transfer possession or where an attempted transfer was for some reason defective. An imperfect gift might nevertheless be given effect by treating the transaction as a declaration of trust. Indeed, the facts of Pye itself suggest that this is exactly what Eldon did. ${ }^{106}$ And in subsequent decisions Chancery did enforce as

Wycherley v. Wycherley, 2 Eden $175,177-78$ (1763). It is possible that Eldon took much the same view of the situation before him in Pye.

104. The importance of the issue of equitable gifts in the United States was indicated in an unsigned book review by Holmes written in his capacity as editor of the American Law Review. Reviewing the tenth edition of Story's Commentaries on Equity Jurisprudence, Holmes observed: 'There are few recently developed doctrines of more interest than that of the voluntary assignment of equitable choses in action. Whether this was not a contract, and so void for want of consideration; how there could be a gift when no delivery was possible; whether there must not be a delivery of the indicia, or an instrument under seal, or notice to the debtor or to the assignee, - these were some of the questions which were raised and passed upon ... [ [I]t is only recently that the rule has been satisfactorily stated . . . '5 American Law Review 115, 115-16 (1870).

105. Roscoe Pound, 'Consideration in Equity', 13 Illinois Law Review 435, 678 (1919). This article is an attack on what Pound called the 'analytical theory' which 'assumes that the whole of the body of law came into existence at one time by one stroke'. Ibid. at 680. Pound's own theory was adaptive: the Chancellors adapted 'such theories and doctrines as were at hand'. Ibid. at 681 .

106. This, at least, is the common view of Pye. See, e.g., Richard V. Wellman, Lawrence W. Waggoner and Olin L. Browder, Jr., Palmer's Trusts and Succession (Mineola, N.Y., 4th ed., 1983) 471. 
trust declarations informal transactions that would have failed as commonlaw gifts because of lack of delivery. ${ }^{107}$

One plausible interpretation of Eldon's decision is that he looked only at whether there was a general donative intent, rather than sharply focusing on a specific trust intent. Concluding that Mowbray's donative intent was firm, Eldon would not permit a technical requirement to interfere with that intent. Equity's approach to consensual transactions prior to the nineteenth century generally was less formal than it became in the nineteenth century. The seventeenth-century principle that Chancery would, upon certain conditions, construe a legally ineffective conveyance as a promise or covenant to transfer, ${ }^{108}$ for example, was reaffirmed in the middle of the eighteenth century. ${ }^{109}$ Enough of this attitude persisted at the beginning of the nineteenth century to permit us to read Pye as one of the last marks of an earlier tradition of informality in Equity.

Equity judges attempted to eliminate the tension between trust and gift later in the nineteenth century. Dissatisfaction with the gratuitous declaration of trust doctrine was evident by 1865 , when Lord Cranworth, correcting the report of an earlier decision ${ }^{110}$ in which he is said to have stated that a '[m]ere declaration of trust . . . in favour of a volunteer, is inoperative', 111 nevertheless labelled the new doctrine 'unfortunate'.112 Finally, in the famous case of Richards $v$. Delbridge, decided in 1874, the Master of the Rolls, Sir George Jessel, settled the principle that Equity will not cure an imperfect gift by treating it as a declaration of trust. Though he accepted the premise of Pye that a gratuitous declaration of trust might be enforced in Equity though there had been no transfer of possession, Jessel declared that if a person intended his transaction to be a gift neither law nor Equity would enforce that intention if delivery was lacking. In other words, Equity would no longer be satisfied, as Eldon apparently was, with proof of a general donative intent; it now required proof that the owner specifically intended to declare a trust.

Jessel's insistence upon a strict distinction between gift and trust intent removed the threat to the legal formalities posed by the anomalous trust declaration device. Richards $v$. Delbridge cabined the scope of Ex parte $P y e$, thereby enhancing the semblance of compatibility between legal and Equitable doctrines. ${ }^{113}$

107. Richardson v. Richardson, L.R. 3 Eq. 686 (Ch. 1867); Morgan v. Malleson, L.R. 10 Eq. 475 (Ch. 1870).

108. Osmere v. Sheafe, Carth. 307, 90 Eng. Rep. 78 (1694).

109. Roe d. Wilkinson v. Tranmere, Willes 682, 125 Eng. Rep. 1381 (1758).

110. Scales v. Maude, 6 D.M. \& G. 43 (1855).

111. Ibid. at 51 .

112. Jones v. Lock, (1865) L.R. (1 Chan. App.) 24, 28 (1865).

113. It is interesting to note that Richards was decided just one year after passage of the Judicature Act of 1873, which institutionally merged the courts of law and Equity. 36, 
2. The Requirement of Definite Beneficiaries: The Trust/Power Distinction

Another example of the nineteenth-century process of drawing categorical boundaries between trust and other legal forms is the distinction between bare powers of appointment and trust powers. The first case sharply distinguishing the prerequisites for valid powers and trust powers was Morice v. The Bishop of Durham. ${ }^{114}$ Lord Eldon's decision in this case, in contrast with his apparent tolerance of informality in Pye,115 enhanced the degree of formality in trust law and sharpened trust law's separate identity.

Morice established different tests for the amount of definiteness required of trust powers and non-trust (bare) powers. In Morice, a testator had bequeathed property to the Bishop of Durham in trust 'to dispose of [the fund] to such objects of benevolence and liberality as the Bishop of Durham in his own discretion shall most approve of'. 116 The bishop was willing and able to carry out the testator's intentions, but Eldon held that the trust was void because it lacked definite beneficiaries. He stated that the trust was 'for purposes not sufficiently defined to be controlled and managed by this Court'. ${ }^{117}$ Despite the fact that the testator gave the bishop discretion concerning the persons to whom he might decide to appoint, Eldon concluded that the power of appointment fell with the trust.

Equity courts had defined the distinction between trust and bare powers prior to Morice. The crux of that distinction is this: a trust imposes a duty upon a trustee; a power confers discretion upon the power-holder (called a donee). If a trustee fails properly to execute his duty, a court will enforce that duty by compelling the trustee to act. But if a donee fails to exercise a power, he has not breached a duty and the appointive property usually will devolve on default of appointment without court involvement.

Chancery judges developed from this distinction separate tests for the

37 Vict. c. 66 (1873). Jessel, who decided Richards, is credited with piloting the Act through the House of Commons as Solicitor General prior to his appointment as Master of the Rolls in 1873. William Holdsworth, A History of English Law, 16 vols. (London, 1966) xvi: 121. Although we should heed Holdsworth's caution against exaggerating the effect of the Act on substantive law, ibid. at xv: 134-36, it is nevertheless tempting to speculate that in Richards Jessel took the opportunity to demonstrate the indirect, if not direct, effect of the Act on eliminating doctrinal conflicts between law and Equity.

114. 10 Ves. 522, 32 Eng. Rep. 947 (Ch. 1805).

115. Eldon's focus on Pye on general donative intent is characteristic of legal informality. Perhaps informality is best explained in this context indirectly by contrasting with the following example of legal formality, taken from Charles Fearne's treatise on contingent remainders: "Surely it is better that the intentions of twenty testators every week should fail of effect, than that those rule should be departed from upon which the general security of titles and quiet enjoyment of property so essentially depend.' [cited in C. H. S. Fifoot, Lord Mansfield (Oxford, 1963) 178.] His approach to the trust powers matter in Morice does seem to be distinctly more formalistic. This contradiction is but one in the career of a truly complex historical figure.

116. 9 Ves. at 399 (1821), 32 Enq. Rep. at 947 . 113. 32 Eng. Rep. at 955.

117. 32 Eng. Rep. at 955. 
degree of definiteness required in the description of trust and power beneficiaries. In case of a trust, they reasoned, all potential beneficiaries must be ascertainable because Chancery would enforce the trust by ordering equal distribution among all of them. But as to a mere power, there is no need to identify the entire range of beneficiaries since the court will not have to decree equal division among all permissible recipients (called objects). A bare power is indefinite only if the donor's stated criterion is so imprecise that the donee will not be able to exercise the power in any person's favor with reasonable certainty that that person fits the donor's description.

What made Morice troublesome was the fact that the bishop's power was a tertium quid, a 'power in the nature of a trust'. Should this hybrid power be treated the same as a bare power, or should the court require that it meet the more stringent test of definiteness required of trusts? Two years before Morice, Eldon had described the relationship between hybrid powers and the other two categories in Brown v. Higgs:

But there are not only a mere trust and a mere power, but there is also known to this court a power which the party to whom it is given is entrusted with and required to execute; and with regard to that species of power, the court considers it partaking so much of the nature and qualities of a trust, that if the person who has the duties imposed upon him does not discharge it, the court will, to a certain extent, discharge the duty in his room and place. ${ }^{118}$

In other words, a trust power, like a trust and unlike a bare power, is mandatory. The donee (trustee) is under a duty to execute the power, and if he does not do so the court will. But Eldon did not clearly indicate in Brown the manner in which the court would execute the trust.

In Morice, Eldon transformed what had been a flexible principle into a formal rule that invalidated a substantial number of trust powers. During the late seventeenth century Lord Nottingham had stated the rule that the court would order equal distribution among all of the beneficiaries as a presumption. ${ }^{119}$ The older cases indicate that Equity judges were willing to control the trustee's discretion over powers. ${ }^{120}$ Longmore $v$. Broom, ${ }^{121}$ decided in 1802 , signalled a change in attitude. The court there stated that it had no discretion to order any distribution other than equal among all beneficiaries. But in Morice there was no need for the court to enforce the power since the trustee was willing to exercise the power. Nevertheless Eldon held, in what James Barr Ames later called a 'monstrous non sequitur', ${ }^{22}$ that a willing

118. 8 Ves. 561,570 (1803).

119. Craker v. Parrett, 2 Freeman 18, 2 Chan. Cas. 228 (1677); Gibson v. Kenyon, 1 Vernon 66 (1682); Woolaston v. Swetnam (1677), D. E. C. Yale, Lord Nottingham's Chancery Cases, vol. 2, Case No. 770, 79 Selden Soc. 587 (London, 1961).

120. Mosley v. Mosley, (1673) Rep.t.Finch; Clarke v. Turner, 2 Freeman 198 (1694); Warburton v. Warburton, 1 Bro. P.C. 1 (1702).

121. 7 Ves. 125 (1802).

122. James Barr Ames, 'The Failure of the Tilden Trust', 5 Harvard Law Review 389, 395 (1892). In his famous debate with Ames over Morice v. The Bishop of Durham John Chipman Gray explicitly defended the decision on the basis of preserving the 
trustee/donee may not exercise a trust power where not all of the objects can be ascertained. By ruling that the validity of a trust power depended completely upon the validity of the trust itself, Eldon sharpened the categorical distinction between trust and power. As a result Equity thereafter violated donors' intentions in a much wider range of cases.

This sharp distinction, which Equity judges have questioned only recently 123 indicates the extent to which the Chancery judges in the nineteenth century were concerned about the peculiar nature of the trustee's duties. Their effort to distinguish between powers and trusts (including powers impressed with a trust) derived from a desire to clarify the role of the trustee as bound by a peculiar sort of duty. The essence of the theory of the trust, after all, is that a trustee holds title to trust property for the benefit of other persons to whom he owes duties. It was important to nineteenthcentury Equity judges that these fiduciary duties not be confused with contractual duties.

Treating bare powers and trust powers alike might have softened the notion that trusts differ from contractual arrangements in the special nature of trustees' duties. Legal theory had already drawn a sharp distinction between fiduciary duties and promissory duties. Increasingly in the nineteenth century the social vision underlying legal rules relating to contractual duties stressed the impersonal aspect of human interactions, self-protecting individuals dealing at arms length with each other in atomized relationships. ${ }^{124}$ The conception of fiduciary duties deviated from this social vision by stressing the protective function of the fiduciary office. Within the unusual world of fiduciary relationships, people were entitled to hold special expectations. Just as expectations within the family are greater than those within the impersonal world of work, so legal thought considered that beneficiaries are entitled to expect more of fiduciaries than self-interest.

Having underscored the dichotomy, doctrine at the same time sought to mediate the contrast between these two conceptions of duty. By developing clear categorical distinctions, nineteenth century legal thought prevented the

categorical distinction between a power and a trust. Similar to the reasoning behind Richards v. Delbridge, Gray argued that an invalid trust could not be treated as a valid power:

When a power is given ... a an appointment under the power is good, although there is no one who can compel the exercise of the power; there is no duty intended to be imposed on the donee of the power to exercise it. But when there is is an intention to impose a duty, to create a trust, then the doctrine of Morice $v$. The Bishop of Durham is that . . . if there is no cestui que trust, the trust is invalid.

J. C. Gray, The Rule against Perpetuities (Boston, 3d ed., 1915) 909a. See also J. C. Gray, 'Gifts for a Non-Charitable Purpose', 15 Harvard Law Review 509, 513, 514 (1902).

123. See McPhail v. Doulton, [1970] 2 W.L.R. 1110.

124. I will not attempt here to establish that there was a connection between the ethic of individualism and contract law in nineteenth-century England. I am content to rely on P. S. Atiyah, supra note 51 , where the connection is made convincingly in my opinion. 
notion of special fiduciary duties from undermining the individualistic ideology that underlay the conception of contractual duties. Eldon's treatment of trust powers in Morice helped to secure the dominance of the individualistic contractual duty by bracketing the fiduciary category.

In general, the process of drawing categorical lines between trust and other legal forms served an ideological function. It reinforced the ascendent contractarian mentality, preventing it from being destabilized by the competing non-contractarian principle that is embedded in the very theory of the trust, that is, the notion that at times one has a duty to treat others' interests as though they were one's own. The nineteenth-century categorical structuring of private law allowed the legal systems in both England and the United States to recognize this principle but restrict its scope to an isolated, marginal corner of private law.

\section{The Classical Reordering of Trusts, 1875-1914}

With the categorical boundaries between trust and non-trust arrangements fairly well defined by the mid-nineteenth century trust law was now a recognizably distinct and formal legal category. This is indicated, to some extent at least, by a change in the scope of the professional literature relating to trust law, both in England and the United States.

Until the middle of the nineteenth century virtually all of the treatises relating to trusts ${ }^{125}$ follow the model set in the seventeenth century by Bacon's Reading on the Statute of Uses. These monographs described their subjects as being 'uses' rather than 'trusts'. Specifically, they treated, in a practical way, the effects of the Statute of Uses on conveyances. ${ }^{126}$ In effect

125. Two aspects of this literature are worth mentioning. First, virtually all of it is English. The first treatise on the law of trusts written by an American was not published until 1872, although it became very influential within the American legal professional almost immediately after its publication. The work was Jarius W. Perry, A Treatise on the Law of Trusts and Trustees (Boston, 1872). Prior to the appearance of Perry's work, American lawyers and courts in the nineteenth century primarily used American editions of the famous English treatises.

The second point about the early trusts literature is that virtually all of it was, until the very end of the nineteenth century, professional rather than academic. The treatises genuinely were, as the titles of several indicated, 'practical'; they were written by practitioners with practical, not academic objectives.

For an interesting discussion of the changing forms of legal treatises, see A. W. B. Simpson, 'The Rise and Fall of the Legal Treatise: Legal Principles and the Forms of Legal Literature', 48 University of Chicago Law Review 632 (1981).

126. Among the early professional writings on trusts are the following works: Geoffrey Gilbert, The Law of Uses and Trusts Collected and Digested in a Proper Order from the Reports of Adjudged Cases, in the Courts of Law and Equity and Other Books of Authority Together with a Treatise of Dower (London, 1st ed., 1734); William Cruise, An Essay on Uses (London, 1st ed., 1795); Francis W. Sanders, An Essay on Uses and Trusts and on the Nature and Operation of Conveyances at Common Law, and of 
they treated trusts (or uses) as a subpart of the law of conveyancing and settlements. By the middle of the century, however, following the end of Eldon's Chancellorship, a different type of trust treatise began to appear. These works were exclusively about trusts and trustees. ${ }^{127}$ They dropped the earlier focus on uses and the Statute of Uses. They organized the principles of trust law in a manner that would be substantially familiar to the modern lawyer. Of this mid-century body of trust writing, in fact, two works continue to be published under the original authors' names, and both are widely known within the profession. ${ }^{128}$

Another clear indication of trust law's status as an autonomous legal category in late nineteenth-century American legal consciousness was the appearance of the first casebook on trusts in 1882. ${ }^{129}$ Prepared as the text for a separate course on trusts at Langdell's Harvard Law School, James Barr Ames's Cases on Trusts ${ }^{130}$ was the model for the modern American law school casebook on trust law. The book's structure strongly reflects the formalized theory of the trust. The first chapter, which occupies nearly half of the entire book, is entitled, 'The Nature and Requisites of a Trust'; it begins by distinguishing trust from other legal categories, including debt and bailment, and later includes individual sections on the requisite elements of a trust. Rather than treating trusts as a species of conveyancing, Ames abstracted trust as a legal category and focused attention on its peculiar features. ${ }^{131}$

Those Which Derive Their Effect from the Statute of Uses, 2 vols. (London, 4th ed., 1824).

127. Among these works are the following: Thomas Lewin, A Practical Treatise on the Law of Trusts and Trustees (London, 1st ed., 1837); James Hill, A Practical Treatise on the Law Relating to Trustees, Their Powers, Duties, Privileges, and Liabilities (London, 1st ed., 1845); A. Underhill, A Concise Manual of the Law Relating to Private Trusts and Trustees (London, 1st ed., 1878); H. Godefroi, A Digest of the Principles of the Law of Trusts and Trustees (London, 1st ed., 1879).

128. These are the treatises associated with Hill and Lewin, see note 127 supra.

129. Indeed the appearance of a separate course on trusts in the law school curriculum was itself a sign of trust's autonomous status in late-nineteenth century legal consciousness. Austin Wakeman Scott pointed out that before James Barr Ames first introduced his separate Trusts course at Harvard Law School in 1882 the subject was covered in a general course on Equity. Some fifty years later, Scott wholly approved Ames's innovation:

It is believed that the importance of the subject and the peculiar characteristics of the trust justify its treatment as a separate subject for study.

Austin W. Scott, 'Fifty Years of Trusts', 50 Harvard Law Review 60 (1936). Ames's influence on Scott, his former student and then colleague, is evident in Scott's arrangement of the Restatement of Trusts, of which he was Reporter, and in much of his scholarship.

130. James Barr Ames, A Selection of Cases on the Law of Trusts (Cambridge, Mass., 1st ed., 1882).

131. An important factor that influenced trust's emergence as a discrete legal subject in the law school curriculum was the decline of the conception of Equity as a broad system 
While academic writers like Ames and practitioners like Hill and Lewin produced general texts on the law of trusts, other legal scholars during the last quarter of the nineteenth century began to devote considerable attention to the internal classification of trusts. Prior to this time legal writers paid virtually no attention to this topic. During the Classical era, roughly between 1875 and 1920, some of the most important legal writing on trust law, both in the United States and England, discussed classification in detail.

A variety of factors, legal and non-legal, undoubtedly contributed to the new interest in trust classification. As I have already discussed, 132 classification in general was an important aspect of Classical legal thought, ${ }^{133}$ and efforts to classify trust types was certainly a part of the larger enterprise. That larger project in turn can be linked with the Classics' view of law as a science. The Classical version of legal science was consciously patterned after the conception of science that contemporaneously developed among the natural sciences. ${ }^{134}$ Following the example of their counterparts in geometry and biology, the self-styled legal scientists wanted to develop law into an ordered conceptual hierarchy. ${ }^{135}$

Moving beyond these fairly obvious explanations, I want to suggest that

of jurisprudence, encompassing and integrating many different topics. Increasingly through the nineteenth century legal texts defined Equity technically. Under this influence Equity as a subject became narrower, as legal writers pruned from it a variety of topics that they thereafter treated as autonomous legal subjects. These included trusts and mortgages, to name just two. Despite its increasingly narrow scope, however, Equity remained a staple of the law school curriculum throughout the first several decades of the twentieth century. At Harvard, for example, Sidney Post Simpson declared that Equity would remain a separate course as long as he 'had anything to say about it'. Laura Kalman, Legal Realism at Yale, 1927-1960 (Chapel Hill, 1986) 64.

132. See Part I. A. supra.

133. For an excellent discussion of the role that classification played in Classicism's desire to make the legal system a formal conceptual order, see Grey, supra note 5 at $1,8-10$, $47-50$.

134. The single best discussion of the influence of the late-nineteenth century idea of science on Classical American legal thought of which 1 am aware is Grey, supra note 5 at 1 , 16-32. Grey argues, persuasively in my judgment, that among the sciences geometry provided a closer model than the new evolutionary biology. For geometry, but not taxonomic biology, was like law in using 'its intellectually ordered system not only to classify specimens but also to solve problems.' Ibid. at 30 .

135. The Classical lawyers explicitly wrote about the need for 'scientific' classification schemes. See, e.g., C. C. Langdell, Summary of the Law of Contracts (Boston, 2d ed., 1880) viii-ix. Holmes emphasized the need for a 'philosophical' arrangement of the law. His vision was unscientific, or at least unLangdellian, in the sense that he did not think that it was possible to derive legal judgments from abstract concepts and categorical arrangements alone: 'Law is not a science, but is essentially empirical. Hence, although the general arrangement should be philosophical, even at the expense of disturbing prejudices, compromises with practical convenience are highly proper.' Holmes, 'Codes, and the Arrangement of the Law', 5 American Law Review 1 , reprinted in 44 Harvard Law Review 725 (1931). See also O. W. Holmes, The Common Law (M. Howe, ed., Cambridge, Mass., 1963; 1st ed. 1881) 104 and O. W. Holmes Collected Legal Papers (New York, 1920) 195-97. 
the very emergence of trust law as an autonomous legal category was the catalyst for the Classical effort on both sides of the Atlantic, to develop an analytically sound internal arrangement of trust types. The pre-Classical view of trust as a merely derivative legal arrangement, a first cousin of property, limited the felt need for an internal arrangement of trusts. Once trust law was established in legal consciousness as a discrete subject, it seemed appropriate to have a complete and internally coherent outline that listed all of the types of trusts that Equity judges had recognized. And it was perhaps even more important to Classical legal scholars that the classificatory scheme correctly analyzed the legal relationships among the various trust types.

We can sense the growing interest in classification of trust types by comparing the discussions of classification in early and late nineteenthcentury trust treatises. Lewin's treatise, for example, devotes only two pages to classification. ${ }^{136}$ And those pages treat a categorical distinction that was unimportant in later texts, a division between 'simple' and 'special' trusts. ${ }^{137}$ The trust categories that most concerned the Classics, resulting and constructive trusts, are discussed in one chapter entitled, 'Creation of Trusts by Act or Operation of Law'. That discussion, however, indicates no awareness of the theoretical dilemma involved in the by act/by law distinction that so concerned Classical trust scholars.

In contrast, the later treatises contained much more extensive and sophisticated discussions of trust classification. And it was not just the academic writers who took classification more seriously. For example, in Perry's treatise, 'intended for the daily use of the lawyer in busy practice', 138 devotes three extensive chapters each to the 'implied', 'resulting', and 'constructive' categories. ${ }^{139}$ Among the academic texts, Pomeroy's influential multi-volume treatise on Equity, first published in 1886,140 contains an extensive analysis of trust classification. Pomeroy's discussion is particularly revealing, for it singles out for special treatment the topic of trusts that are created by operation of law. After first distinguishing between private and public (charitable) trusts, Pomeroy turns his attention to the distinction between express trusts and trusts arising by operation of law. It is worth quoting a lengthy passage because, as we shall shortly see, ${ }^{141}$ Pomeroy's analysis of the distinction, which followed the views of other

136. Thomas Lewin, A Practical Treatise on the Law of Trusts and Trustees (London, 1837) 21-22.

137. Compare, for example, Perry's discussion of this distinction in one paragraph, while devoting entire chapters to the 'implied', 'resulting', and 'constructive' categories. Perry, supra note 125 at $11,112-23,124-65,166-230$.

138. Lewin, supra note 136 at $\mathrm{v}$.

139. See note 97 , supra.

140. John Norton Pomeroy, A Treatise on Equity Jurisprudence, 3 vols. (San Francisco, 1886).

141. See text accompanying note $152-59$, infra. 
writers, contained elements of pre-Classical thinking that other writers later purged:

The second main division of trusts, and the one which, in this country especially, affords the widest field for the jurisdiction of equity in granting its special remedies so superior to the mere legal recoveries of damages, embraces those which arise by operation of law, from the deeds, wills, contracts, acts, or conduct of parties, either with or without their intention, but without any express words of creation. A broad distinction separates all express trusts from those which arise by operation of law. In the former class the trust relation is rightful and permanent. In the latter, there is no such element of right and permanency. ... All trusts which arise by operation of law, are, as the name indicates, excepted from the requirements of the statute of frauds. This entire grand division consists of two general classes: resulting trusts and constructive trusts. The line of distinction between these two classes is clear and definite; the failure to observe it has produced much unnecessary confusion. ${ }^{142}$

Probably the most influential statement of the conventional trust classification scheme during the second half of the nineteenth century was Maitland's discussion of the topic in his famous Equity lectures. ${ }^{143}$ At least it was Maitland's arrangement that George Costigan attacked at the close of the Classical era. ${ }^{144}$ Costigan's rearrangement of trust types in many respects was more faithful to the central tenets of Classical legal thought than either Maitland's or Pomeroy's, despite their presence in the Classical period. ${ }^{145}$ To see why the internal classification of trusts was important to the Classical outlook and why Classics like Costigan ${ }^{146}$ regarded Maitland's

142. Pomeroy, supra note 100 at ii: $602-604$.

143. F. W. Maitland, Equity and the Forms of Action (A. H. Chaytor and W. J. Whittaker, eds., Cambridge, 1932). The influence of Maitland's view on the arrangement of trusts is evident in Pomeroy's discussion quoted in the text. See text accompanying note 142 supra.

144. Costigan credited Maitland with the classificatory scheme that is set out at text accompanying note 148 infra, but Maitland himself acknowledges that the scheme is just a synthesis of discussions by other writers, particularly Lewin. See George Costigan, 'The Classification of Trusts as Express, Resulting, and Constructive', 27 Harvard Law Review 437 (1914) ('A conventional statement of the matter and a common arrangement of the terms were given by Maitland ...').

145. I do not mean to suggest that Maitland was a 'Classical' writer in the sense in holding to most, or any, of the major points with which Classical legal thought is associated. However, he did share common interests and methods with important American Classical figures like James Barr Ames, and in fact he corresponded with them.

146. George Purcell Costigan, Jr., was a transitional figure, bridging the late Classical period and Legal Realism. He was a law professor for thirty-four years, from 1900 to 1934. An 1894 Harvard Law School graduate, he evidently was influenced by Langdell and Ames. His early essays reflect a characteristically Langdellian concern with legal classification and definition. For example, one essay, 'A Plea for a Modern Definition and Classification of Real Property', 12 Yale Law Journal 425 (1903), argued that by remodelling the classification of real property interests, 'much can be done . . . to simplify the treatment of real property'. Ibid. at 439. This article also reflects Gray's influence in its suggestion that the law-school property course should be structured on the basis of a scheme for classifying property interests. See text accompanying notes 33-34 supra. Orrin McMurray, in an obituary upon Costigan's death in 1934, 
arrangement as needing revision, we shall, in the remainder of this Part, compare the two arrangements, Maitland's and then Costigan's reclassification.

Maitland first states that treatise writers ${ }^{147}$ commonly distinguish between two modes of creating a trust, by act of a party and by operation of law. He then summarizes the conventional arrangement of trust types in relation to that dichotomy: 148

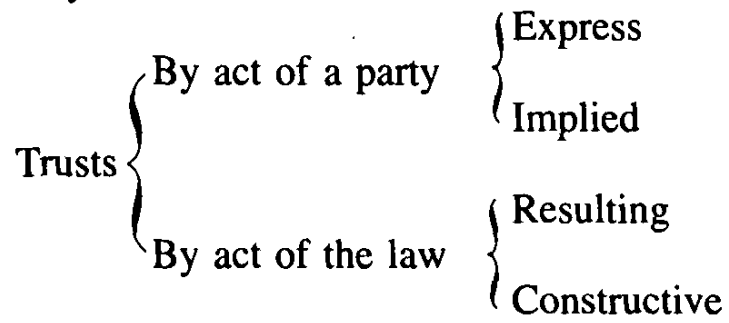

suggested that while Costigan's early writing 'follow[ed] the Harvard tradition of the nineties . . . [by] improving classification and definition in the law', his later scholarship reflected an outlook that McMurray termed the 'free school of jurisprudence': 'Down with the "legal estate", divide the loss "fifty-fifty"!' Orrin McMurray, 'George Purcell Costigan, Jr.', 24 California Law Review 1, 3 (1935). Albert Kokourek's evaluation of Costigan's work is similar, although more probing:

Legal truth in 1894, when Professor Costigan graduated from the Harvard Law School, somehow seemed to be simpler than it appeared in 1914, when he was at the height of his powers. Twenty years later, when he laid aside forever the familiar green bag .... , the legal truth of the generation before had in some respects became [sic] an alien thing. What we mean to suggest here . . . is the transition from the conceptional attitude of the era of those great masters, Ames, Gray, and Thayer, and their epigones, among whom Professor Costigan was certainly not the least, to what has been called 'realism' by some of its followers, and romanticism by some of its detractors. In this respect, however, the story of the law has not been different from that of mathematics, physics, or astronomy.

Albert Kokourek, 'In Memoriam-George Purcell Costigan', 29 Illinois Law Review 769, 771 (1935).

147. Maitland's classification was largely derived from Lewin's treatise. Although he did not invent the scheme, Lewin certainly contributed to its widespread acceptance among English and American trust lawyers. Maitland especially drew on his chapter on trusts created by operation of law. See Lewin, supra note 136 at 168-224.

148. Maitland, supra note 143 at 53. In the United States, both Perry's and Pomeroy's treatises similarly classified resulting and constructive trusts as created by operation of law. However, both are equivocal about the precise role of law in the creation of these trusts, mixing together positive acts of law (will of the state) and private intentions (will of the individual). For example, Perry describes resulting trusts as trusts 'which result in law, from the acts of parties whether they intended to create a trust or not . . . ' Perry, supra note 125 at 97 (emphasis in the original). Later, his description of constructive trusts more clearly separates constructive trusts from the other three types on the basis of the irrelevance of private intention in its creation: '[Constructive trusts] differ from other trusts in that they are not within the intention or contemplation of the parties at the time the contract is made from which they are construed by the court, but they are thrust upon a party contrary to his intention and against his consent.' Ibid. at 136. On Pomeroy's classification, see text accompanying notes 140-42 infra. 
Although he did not propose any changes in this arrangement, Maitland, unlike Lewin, was aware of its problematic aspects. First, he realized that the express/implied distinction, expressed as a sharp dichotomy in the outline, in fact was vague: 'the distinction comes to be one between clear and less clear words, and clearness is a matter of degree'.149 More importantly for our purposes, Maitland pointed out the central ambiguity in the category of 'implied' trusts. Drawing an analogy between classification in contract law and trust law, he indicated why trusts created by operation of law in a sense are implied trusts:

When studying the law of contract your attention will have been drawn to a very similar, a parallel, ambiguity sometimes 'Implied Contract' stands for a true contract constituted rather by acts than by words, sometimes it stands for a 'Contract implied by law,' or 'Quasi Contract,' an obligation which is no true contract but which is treated for many or most purposes as though it was a contract. Turning now to trusts 'created by operation of law,' we might similarly call them 'Quasi trusts'; but that term is not in use. ${ }^{150}$

In this passage Maitland anticipated Costigan's objection to the conventional use of the 'implied trust' category. For, as Maitland noted, that term was often used interchangeably with 'by operation of law', and because of the breadth of the 'implied trust' category, one can easily get the impression that law, not private intentions, creates trusts in a great number of situations. That suggestion, if generally accepted, would have contradicted the ideology around the Classical writers increasingly organized both contract and trust law beginning in the last decades of the nineteenth century, the will theory.

Maitland failed to pursue the dilemma that he had discovered. His remarks on the resulting trust and constructive trust categories basically repeated Lewin's analysis, although with characteristically greater style and subtlety. Specifically, he did not acknowledge any need to clarify the whole topic of implied trusts and their relationship to trusts created by operation of law. It was that task which Costigan undertook in his 1914 article, 'The Classification of Trusts as Express, Resulting, and Constructive'.

Costigan's objectives were to demonstrate the analytical errors in Maitland's arrangement and to propose a comprehensive reclassification of trusts according to their modes of creation. At the end of the article he gave the following outline summary:

149. Maitland, supra note 143 at $75-76$.

150. Ibid. at 76 . 


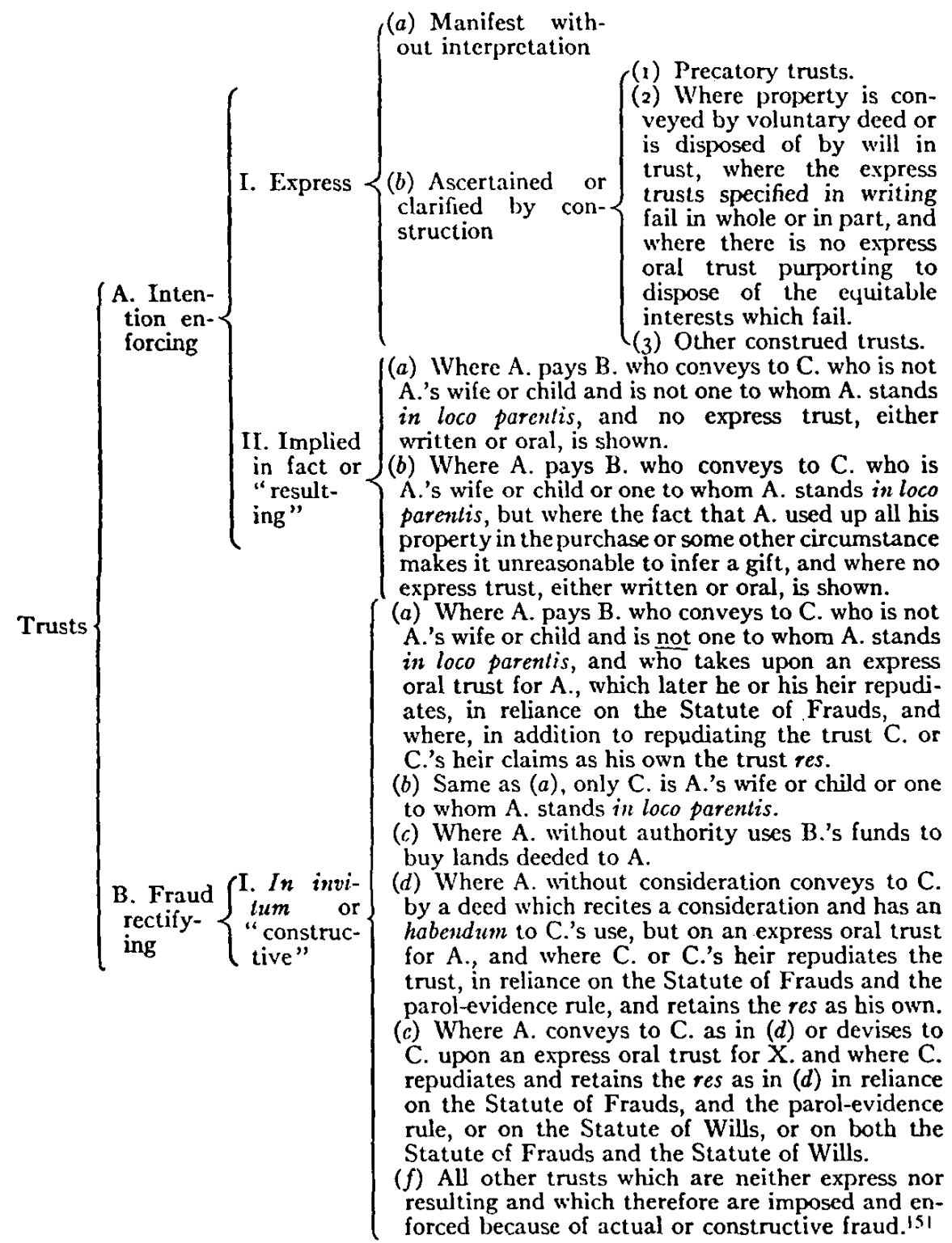

This scheme changed Maitland's outline in three important respects. First, it narrowed and clarified the 'implied trust' category by specifying that trusts can be implied only in fact, not in law, i.e., from private intent not the intent of the state. Second, it removed resulting trusts from the category of trusts created by operation of law and treated them as created by implication from private intention. Finally, it isolated the constructive trust as the only type that is not 'intention enforcing'. Indeed, as I will later discuss, it diluted, in theory, the extent to which the judicially-created constructive

151. Costigan, supra note 144 at 462 . 
trust device overrides individual will by labelling these trusts 'fraud rectifying'. The ultimate effect of these changes was to bring trust classification into line with the then-dominant will theory, which had similarly reorganized the categories of contract. ${ }^{152}$

Costigan's impatience with the old 'implied trust' category can be understood as a Classical reaction against pre-Classical thinking. Consider again the following statement in Pomeroy's treatise which we quoted earlier: '[trusts] arise by operation of law, from the deeds, wills, contracts, acts, or conduct of parties, either with or without their intention. . .'.153 What strikes us as surprising about this explanation today is its failure clearly to distinguish between legal actions that are undertaken to enforce private intentions and those judicial acts that have some design other than facilitating private intentions, what we would today call regulative. But our perspective reflects the influence of Classical thinking, while Pomeroy had not yet fully integrated Classicism into his analysis.

Pre-Classical writers, during the early to mid-nineteenth century, did not experience the need to draw any sharp contrast between law as facilitative, i.e., designed just to enforce private intentions, and law as regulative, i.e., designed to implement the state's will. Several features of pre-Classical legal thought blunted the writers' perception that individual and state wills conflicted with each other. Among these features, the notion of a tension between 'morality' (or 'natural' law) and 'policy' (or the general good, pragmatically defined) ${ }^{154}$ to some extent prevented pre-Classical writers from perceiving any clash of wills. Even more importantly, the pre-Classical theory of adjudication, which posited that judges found, rather than created law, ${ }^{155}$ precluded a sense of conflict even between morality and policy by treating both as sources of law to which a judge might legitimately turn in the process of discovering the law. ${ }^{156}$

152. In this sense, Costigan's reformulation of the theory of the constructive trust can be linked to what Morton Horwitz describes as "a general attack upon "equitable" standards that began much earlier in the nineteenth century'. Morton Horwitz, 'Book Review', 42 University of Chicago Law Review 787, 789 (1975) (reviewing Grant Gilmore, The Death of Contract).

153. Pomeroy, supra note 140 at 602.

154. For this discussion, I have benefitted from Duncan Kennedy's unpublished work, The Rise and Fall of Classical Legal Thought, 1850-1940 (1975), especially chapters III and IV.

155. I do not mean to suggest that the discovery theory of adjudication was peculiar to pre-Classical English or American legal thought. My point is simply that it was decidedly more influential prior to the Classical period.

156. Another feature of pre-Classical thought that helped to avoid the sense of conflict in property law was the influence of so-called technical reasoning. Although pre-Classical writing generally objected to 'technicality', the law of property was the one area in which writers were willing to accept a certain degree of technicality as unavoidable and even desireable. I discuss how technicality influenced the pre-Classical handling of the 
For a variety of reasons that I cannot go into now, the pre-Classical conceptual apparatus lost its credibility during the second half of the nineteenth century, and the ideas that made up what I have been calling Classical legal thought gained influence. The emergence of the will theory was a crucial part of this broad transformation. In its fully developed version, the will theory was both a theory of adjudication and a general doctrinal rationale for all areas of private, consensual social activity. It conceived the function of virtually all of private law to be facilitating the private wills of individual actors in transactions, subject, however, to limitations imposed by the will of the state in order to protect certain larger community concerns.

The emergence of the will theory precipitated a rethinking of the whole process of judicial implication. The fuzzy pre-Classical notion of implied trusts (and, similarly, implied contracts) blurred the distinction between the parties and the judge, the individual and the state. What was the actual source of rights and duties under an implied trust, the wills of autonomous legal actors or the collective will of society expressed through judiciallycreated doctrines? ${ }^{157}$ The Classical concept of will required the source be explicitly identified.

Costigan's sharp reaction to the ambiguity he saw in the "implied trust" category reflected the influence of the will theory in the law of trusts. Specifically, the will theory explains his insistence that the only trusts that are actually created by implication are those that are implied from private intentions. To underscore this point, he proposed substituting the phrases 'intention enforcing' and 'fraud rectifying' for the old 'express' and 'implied' headings. So narrowed, the only trust type that is actually created by implication is the genuine resulting trust, and Costigan called these 'intention trusts'. ${ }^{158}$ He lucidly explained why writers like Pomeroy thought

problem of restraints on alienation in Gregory S. Alexander, supra note 88, at 1189 , $1209,1227$.

157. As Duncan Kennedy notes, the will theory was positivist in the sense that its adherents never acknowledged that judges decided on the basis of their own personal views. Even when overriding individual will, judges followed someone else's directives, if not the individual's, then the sovereign's. This is why even though intention-overriding devices like the constructive trust were judge-made, American will theorists never perceived such doctrines as undemocratic. Those doctrines merely implemented some larger policy whose preeminence had been dictated by the legislature or community norms.

158. Costigan, supra note 144 at $448 \mathrm{n} .30$ and 452 . The influence of the will theory on Costigan's rearrangement is even more clearly evident in the way that he revised the category of resulting trusts. Costigan argued that many courts, and also scholars like Pomeroy, had incorrectly applied the label 'resulting' to certain situations that analytically, although not historically, involved constructive trusts. Briefly, the argument was as follows.

Since resulting trusts are intention-inferring trusts and constructive trusts are law-imposed trusts, genuine resulting trusts exist only where trust intent is established on the basis of a presumption of fact, i.e., of the transferor's probable intent. But where the transferor's intent to create a trust is demonstrated by actual proof, rather than through a presumption, there is no analytical basis for calling the trust intentioninferring. In such situations, the trust is not the resulting variety but rather is 
that resulting trusts are implied by law and why their analysis was mistaken:

In a sense resulting trusts are implied by law, because it is the court that indulges the presumption of fact [i.e., of the transferor's intent to create a trust]; but since the presumption of a resulting trust is in essence one of fact, such a trust is presumed as an actually intended trust and so is fundamentally not implied by law. A resulting trust, properly so called, is a law-inferred-as-a-fact trust. . . .159

The most important consequence of Costigan's revision of the implied trust category was that it isolated constructive trust as the only trust type that was 'law-imposed'. ${ }^{160}$ It is tempting to explain Costigan's separation of resulting and constructive trusts as an attempt to limit the magnitude of trusts that are created by positive law regardless of intent. But that interpretation would overlook the complexity of both the will theory itself and Costigan's scheme. For Costigan, while explicitly embracing the constructive trust device, subtly revised its theoretical foundation in a way that softened the apparent conflict between constructive trust and intention trusts.

Costigan's discussion of constructive trust evinces no sense of hostility toward that device. Quite the opposite, part of Costigan's message was that courts ought more frequently to use the constructive trust device to overcome the technical Statute of Frauds impediment to imposing obligations on transferees who orally promised to hold transferred land for

constructive. The court enforces the transferor's express trust intent in order to prevent fraudulent retention of the trust property by the transferee who is claiming the property for himself. Ibid. at 455-59.

Costigan made the same argument for distinguishing between resulting and constructive trusts in another article published during the same year, 'Trusts Based on Oral Promises to Hold in Trust, to Convey, or to Devise, Made by Voluntary Grantees', 12 Michigan Law Review 427 (1914). In this article he argued that where property had been transferred on the basis of an oral (and therefore, under the Statute of Frauds, unenforceable) promise to hold in trust, relief could not be granted for breach of the promise by declaring a resulting trust, since the existence of an express promise meant that there was nothing to infer. Such a situation properly belonged in the category of constructive trusts, which are not inference trusts, but a device for avoiding unjust enrichment. The real problem was whether a constructive trust could be declared where the promise was honestly made but later breached. Costigan's answer was that although there was an honest acquisition of legal title, breach of the promise resulted in a dishonest acquisition of the equitable title of the intended beneficiary, putting the case into the realm of fraud in the acquisition and thereby warranting constructive trust relief. Ibid. at 433-34.

For discussion of how under the influence of the will theory contracts theorists previously had narrowed the 'implied' contract category to contracts implied in fact, see Morton Horwitz, The Transformation of American Law, 1780-1860 (Cambridge, Mass., 1977) 185 (W. W. Story's 1844 contracts treatise 'completely obliterated "implied in law" contracts by insisting that all implied contracts were those "implied in fact" ') and Duncan Kennedy, The Rise and Fall of Classical Legal Thought, supra note 154 at iv, 17 and iv, 24.

159. Costigan, The Classification of Trusts, supra note 144 at 449-50 (footnote omitted).

160. Ibid. at 450. 
another's benefit. ${ }^{161} \mathrm{He}$ augmented the constructive trust category by pointing out that some of what courts commonly call resulting trusts analytically are better viewed as constructive trusts.

There is an apparent paradox, then, in Costigan's treatment of constructive trusts. His schematic revision creates the impression that he wants to cabin the constructive trust and limit its influence. At the same time, his suggestion that courts expand the doctrine's scope undermines this sense of constructive trust's marginal significance. We can resolve this paradox, however, by examining his discussion of unjust enrichment, the theoretical foundation for constructive trusts.

Take the following case, which virtually everyone, including Costigan, conceded to involve a genuine resulting trust. A pays to $B$ the purchase price for some land that B owns absolutely, and B at A's request conveys the land to $\mathrm{C}$ by a deed absolute on its face. This is the so-called purchase-money resulting trust; the law presumes from C's conduct that he agreed to hold the land in trust for A, who paid the purchase price. Costigan rhetorically posed the question why Equity decided to enforce C's implied-in-fact promise, and his answer very deftly provided a bridge between resulting trust and constructive trust. It is worth quoting his answer at length, for it reveals how he dissolved the tension between intention trusts and law-imposed trusts, consistently with the dictates of the will theory:

The answer of chancery judges to that question, and their only possible answer, is that it is against conscience to permit $\mathrm{C}$. to enrich himself at $\mathrm{A}$.'s expense contrary to the ascertained intention of the parties, by repudiating his implied-in-fact promise or his express promise and keeping the property. But unjust enrichment is just as much the basis of a constructive tr ust as of a resulting trust or of an express trust, even though the constructive cestui should be deemed to have a quasi-contractual claim against the constructive trustee. . . . A resulting trust, unlike a constructive trust, is an intention

161. Section eight of the Statute of Frauds explicitly dispenses with the requirement of a writing to prove trusts that are created by operation of law. 29 Car. 2, c. 3, s 8 (1677). Costigan began his article by stating that this limitation on the scope of the Statute of Frauds is one immediate reason for reworking the familiar arrangement of trust types. Having concluded that resulting trusts are not implied by law might seem to have put Costigan in a quandry about the continued applicability of section eight to these cases. By a truly magnificent sleight-of-the-hand maneuver, however, Costigan dismissed the problem with great ease:

That assumption [by the authors of the Statute of Frauds that a resulting trust is implied by law] is wrong, but section eight of the Statute of Frauds was framed by those who believed it to be the right assumption, and, in consequence, resulting trusts have properly been deemed trusts which 'arise or result by implications of law' within the meaning of those words in that section. While resulting trusts properly fall under that section, the wording of that section should not prevent a realization that resulting trusts are after all implied in fact and not implied and that no trusts are properly to be called 'implied by law'.

Costigan, supra note 144 at 450 n.31. Costigan's discussion, in his Michigan Law Review article, of the availability of constructive trust relief in cases of breached oral promises to hold property in trust illustrates the same approach to the theory of constructive trusts. See note 157 infra. 
trust, but an intention trust, whether an express or an implied-in-fact trust, is enforced for the very same fundamental reason that a constructive trust is, namely, to prevent the unjust enrichment of a fraudulent retainer of the property. We are too apt to forget that the sole reason why chancery took jurisdiction to enforce uses, the earliest trusts, was to prevent the unjust enrichment by feofees through their fraudulent retention of land conveyed to them in use or confidence, and that today there is no other reason for chancery's enforcement of any kind of trust.

... [S]ome courts hesitate to raise constructive trusts in the Statute-of-Frauds cases on fraudulent retention alone, though it is fraudulent retention and not fraudulent acquisition that injures the defrauded party and enriches the fraudulent party. . . . [T] he proper principle for their guidance is clear the moment the essential reason for the recognition and enforcement of trusts-the rectification of unjust enrichment-is seen to be the same for all trusts, whether they are express or implied, and whether, if not express, they are resulting or constructive. ${ }^{162}$

This passage resonates with many of the themes of Classical legal reasoning. For present purposes, what we should notice about it is how Costigan expands the unjust enrichment concept to include fraudulent retention as well as fraudulent acquisition ${ }^{163}$ and then how he uses that expanded conception of unjust enrichment to collapse the distinction between intention trusts and constructive trusts. What he had earlier labelled 'law-imposed' trusts have become theoretically compatible with, if not identical to, intention trusts.

Costigan's use of the fraud concept also allowed him to reconcile constructive trust with the will theory's bias toward non-intervention in consensual transactions. Recall that Classicism posited a dichotomy in judicial functions, between intention-facilitating and transaction regulating. The Classical writers were not indifferent as to which of these roles should dominate adjudication of disputes arising from private transactions. Their analyses of doctrinal questions in contract and conveyancing law tilted strongly in favor of the ideology that adjudication was non-interventionist, i.e., that the court's role was merely to discover and effectuate private agreements rather than to regulate the transaction over the intentions of the participants. The fraud concept supported this ideology by rationalizing what apparently was judicial intervention as really a matter of protecting free will. According to Classical writers, if a transaction, such as a conveyance of land, was tainted by fraud, then the arrangement could not be said to be the product of intersecting free wills, for fraud vitiated consent. Imposing a constructive trust upon a person who received or maintained title to land, then, was not judicial intervention that overrides individual intentions. It was not market-negating, but market-confirming.

162. Costigan, The Classification of Trusts, supra note 144 at $452-53$.

163. In his Michigan Law Review article on oral promises to hold in trust, Costigan explicitly repudiated this distinction, stating, ' [T] he old view that fraud at the time of making the promise was actual fraud, and that fraud at the time for performance was constructive fraud, is unsound. In both cases the fraud is actual fraud. Fraud in retention is just as much actual fraud as is fraud in acquisition, and, as actual fraud, calls just as strongly for redress [through the constructive trust device].' Costigan, 'Trusts Based on Oral Promises', supra note 158 at 437-38. 
Costigan concluded his article with a paragraph that expressed his view of the general function of the classification process. He stated:

Correct judicial decisions do not always follow correct legal theory even when that theory is accepted, for correct theory may be misapplied, but the best hope of correct decision lies in the adoption of the best legal theory of rights and remedies. That is the sole excuse for an attempt to correct certain erroneous notions of the nature of resulting and of constructive trusts; but, since those erroneous notions are at times the reason for chancery's failure to furnish the appropriate remedy for fraudulent enrichment, it would seem to be a sufficient excuse for the attempt. ${ }^{164}$

This statement is striking in two respects. First, it indicates Costigan's view that categorical ordering is important not just for the sake of tidiness but because it influences decision-making. This view reinforces Costigan's credentials as a Classical writer. The second notable aspect of the above passage is that it contains no hint of recognition that there were any value or ideological choices involved in rearranging the trust categories. Costigan described the process of classification as strictly neutral. This meant that legal decisions, insofar as courts based them on correct theoretical categories, were themselves non-ideological, or, as the Classics preferred to describe adjudication, 'scientific'.

With the appearance of Costigan's rearrangement of trust types, the transformation of trust law as a legal category was complete. ${ }^{165}$ Costigan's article created a sense of coherence and compatibility in the relationships among the various trust types. Specifically, he was able to stabilize the relationship between constructive trust and the other types by simultaneously extruding it from the process of implication and accommodating its operative principle, avoidance of unjust enrichment, to the intentionfacilitative (i.e., individualist) theory of the remainder of his scheme.

\section{Conclusion}

By the second decade of the twentieth century the transformation of trust law was complete. Trust was no longer merely an adjunct of property law or

164. Costigan, The Classification of Trusts, supra note 144 at 463.

165. As part of his critique of the Restatement of Trusts, Thurman Arnold advocated scrapping the distinctions among express, resulting and constructive trusts altogether. Trusts, he argued, rather should be classified into two types: '(1) Where the trust device is intentionally used to convey property; (2) where it is used by way of analogy to enable the court to give a remedy which the logical implications of some rule of law might deny.' Arnold, supra note 18 at 814 .

Mainstream legal thought has never assimilated Arnold's proposal. For example, the Second Restatement of Trusts retained virtually intact the structure and method of its predecessor. Austin Wakeman Scott, who was Reporter of both Restatements and hardly an admirer of Legal Realism, defended his method and scheme against Arnold's attack in Austin Wakemann Scott, 'The Restatement of the Law of Trusts', 31 Columbia Law Review 1266 (1931). More than any other individual, Scott was responsible for carrying James Barr Ames, conception of trust law into the second half of the twentieth century. Scott's name still dominates the field of trusts as completely as any other figure does any other legal subject. The intellectual history of trust law in the twentieth century would be largely a study of his thought. 
a set of equitable glosses on common-law rules, but an autonomous legal category. The formalized model of the trust, with its constitutive 'elements', was thoroughly embedded in legal consciousness. Legal texts routinely set out the either/or distinctions that identified the categorical autonomy of trust law-trust/debt, trust/agency, trust/bailment, and the other distinctions that law books still analyze today. And legal writers classified trust types consistently with Costigan's scheme.

These nineteenth-century changes in trust law illustrate how legal categorizing masked the ideological character of Classical legal thought. Assimilating trust within the rest of the private legal order prevented trust from undermining the individualistic ideology of related categories. Unable to eliminate those aspects of trust law that suggested communal values, such as the constructive trust device and the charitable trust, ${ }^{166}$ legal thought minimized their destabilizing potential by isolating them. The effect was to generate a structure of private law that was internally coherent and seemingly objective.

The modern legal mind, for all of its supposed sophistication, still clings to this categorical structure and the value choices that that order expresses. It continues to influence law schools' curricula. And it is very much apparent in mainstream legal discourse, which still deploys Classical distinctions ('Is the landlord's duty of habitability derived from property, contract, or tort law?'). We cannot hope to escape that order's value preferences unless we study its categories, emphasizing their contingency and political character. Categorizing may be an inevitable activity, but no particular category is inevitable. We can release the trust form's potential to express communal values, but such a reconstruction first requires that we understand the origins of the category as we now have it. This article has attempted to provide such an understanding.

166. The charitable trust is perhaps an even more obvious locus of the communal vision within trust law. Trust law explicitly acknowledges the special character of trusts created for charitable purposes by exempting them from rules that invalidate noncharitable trusts, including the Rule against Perpetuities and the requirement of definite beneficiaries. Even more significant is the cy pres principle, through which the Chancellor would remedy certain defects in charitable, but not private trusts. The 'public' values served by these-trusts transcended the need to maintain the noninterventionist posture of the legal system in private arrangements. Here again classification prevented it from undermining trust's individualism by drawing the now-familiar categorical distinction between 'private' and 'public', i.e., charitable, trusts. The central problem with the charitable trust, however, was the fact that its hybrid character-neither purely public, nor purely private-prevented courts from drawing this categorical line cleanly. Eldon's difficulty in determining in Morice $v$. The Bishop of Durham whether 'objects of benevolence and liberality' was a charitable purpose cannot be dismissed as an indication of his intellectual limitations. For a study of the dilemma posed by this categorical distinction, see Everett J. Bowman, Intimations of Ideological Change in the History of Cy Pres (unpublished ms. , 1979). See also Stanley N. Katz, Barry Sullivan and C. Paul Beach, 'Legal Change and Legal Autonomy: Charitable Trusts in New York, 1777-1893', Law and History Review 3 (1985) 51 . 